\title{
Research Square \\ Selectively Production of Levoglucosenone from Cellulose via Catalytic Fast Pyrolysis
}

\section{Qian Le}

Guangzhou Institute of Energy Conversion

Liqun Jiang ( $\sim$ lqjiang@ms.giec.ac.cn )

Guangzhou Institute of Energy Conversion https://orcid.org/0000-0002-8541-7539

\section{Zengli Zhao}

Guangzhou Institute of Energy Conversion

\section{Research Article}

Keywords: Levoglucosenone, Magnetic solid acid, Catalytic fast pyrolysis, Cellulose

Posted Date: March 12th, 2021

DOI: https://doi.org/10.21203/rs.3.rs-280794/v1

License: (1) This work is licensed under a Creative Commons Attribution 4.0 International License. Read Full License 


\section{Selectively production of levoglucosenone from 2 cellulose via catalytic fast pyrolysis}

3 Le Qian ${ }^{\mathrm{a}, \mathrm{b}}$, Liqun Jiang ${ }^{\mathrm{a}, *}$, Zengli Zhao ${ }^{\mathrm{a}}$

$4 \quad{ }^{a}$ CAS Key Laboratory of Renewable Energy, Guangdong Provincial Key Laboratory of New and

5 Renewable Energy Research and Development, Guangzhou Institute of Energy Conversion,

6 Chinese Academy of Sciences, Guangzhou 510640, China

$7 \quad{ }^{b}$ Nano Science and Technology Institute, University of Science and Technology of China, Suzhou

8215000, China

9

*Corresponding author: Tel: +86-020-87057721 Fax: +86-020-87057737

E-mail: 1qjiang@ms.giec.ac.cn

Abstract

14 Levoglucosenone (LGO) has a wide range of utilization in the field of organic synthesis. Magnetic solid acid $\left(\mathrm{Fe}_{3} \mathrm{O}_{4} / \mathrm{C}-\mathrm{SO}_{3} \mathrm{H}_{600}\right)$ was used in fast pyrolysis of cellulose to produce LGO. It was demonstrated that the catalyst could promote the pyrolysis of cellulose to produce LGO, but the

17 yield was affected by the pyrolysis temperature and the relative amount of catalyst. The yield of LGO reached $20.0 \mathrm{wt} \%$ from catalytic fast pyrolysis of cellulose at $300{ }^{\circ} \mathrm{C}$, which was significantly higher than that from cellulose $(0.3 \mathrm{wt} \%)$. Furthermore, the kinetic analysis and recycling results showed that the catalyst could not only reduce the required temperature of

21 cellulose in fast pyrolysis, but also still efficiently promote the production of LGO after recovery 22 and activation. 


\section{Introduction}

A great interest burgeons in renewable biomass as a source for fuel and

27 chemicals production for the demands to replace alternatives to fossil fuels (Jiang et 28 al., 2020a). Fast pyrolysis, one of the feasible and effective biomass utilization 29 technology, can convert biomass into bio-oil (Sharifzadeh et al., 2019; Zhang et al., 30 2020). Bio-oil is a complex mixture of water and hundreds of organics including acids, 31 ketones, aldehydes, esters, alcohols, furans, anhydrosugars, phenols and other 32 macromolecular oligomers. Because of containing various compounds and the 33 potential for wide range applications, it can be used as a liquid fuel or extracted 34 valuable chemicals (Tshikesho et al., 2019). However, the concentration of most 35 components in bio-oil obtained from the traditional pyrolysis process is relatively low, 36 and it is currently uneconomical to separate special compounds from bio-oil. There is 37 no doubt that bio-oil production with a high content of target products is essential 38 (Meng et al., 2016). Recently, various selective pyrolysis methods have been 39 investigated, such as pretreatment of raw material before pyrolysis, catalytic pyrolysis 40 of biomass, and optimization of pyrolysis conditions (Zhang et al., 2021; Jiang et al., 41 2020b; Usino et al., 2020). Levoglucosenone (LGO) is an anhydrosugar with a unique structure, which 43 includes not only six different functionalized carbon atoms, but also two chiral centers, 44 containing $\alpha, \beta$-unsaturated ketones and protected aldehyde functional groups. These 45 unique properties make it a chiral synthon for the synthesis of a variety of new and 46 valuable compounds, such as high-value drugs and bio-based polar aprotic solvent 47 (Cao et al., 2015; Zhang et al., 2018; Liu et al., 2020). Although LGO has a 48 considerable value for use, the content of LGO in bio-oil obtained by conventional 49 pyrolysis of cellulose is extremely low, hindering its further utilizations. Therefore, it 
is essential to develop a suitable catalyst for cellulosic fast pyrolysis to achieve LGO with high yields. It has been proposed that the catalysts currently used in the cellulosic pyrolysis to produce LGO include ionic liquids, liquid inorganic acids and solid acids (Doroshenko et al., 2019). Although ionic liquids can increase the yield of LGO significantly, high expenses make them unavailable in large-scale applications (Kudo et al., 2017). Cellulose impregnated with liquid inorganic acids (e.g. phosphoric acid, sulfuric acid) is also performed to promote LGO production (Dobele et al., 1999). However, this process shows several shortcomings: the impregnation of cellulose and acid requires a complicated pretreatment process; a large amount of waste acid is produced after the impregnation, which cannot be recycled and reused. In contrast, solid acid is thermally stable and can be readily recovered after pyrolysis. There is no need to go through a complicated impregnation process and only simple mechanical mixing with the cellulose is required. Therefore, solid acid is a better choice for catalytic fast pyrolysis of cellulose. Solid superacid $\mathrm{SO}_{4}{ }^{2-} / \mathrm{ZrO}_{2}$ was subjected to catalytic pyrolysis, giving a LGO yield of $8.2 \mathrm{wt} \%$ (Wang et al., 2011). Lu et al. (2014a) developed a superacid $\mathrm{SO}_{4}{ }^{2-} / \mathrm{TiO}_{2}-\mathrm{Fe}_{3} \mathrm{O}_{4}$ for catalytic pyrolysis of cellulose at $300{ }^{\circ} \mathrm{C}$, obtaining a LGO yield up to $15.4 \mathrm{wt} \%$. Phosphoric acid-activated carbon catalyzed pyrolysis of cellulose greatly improved the yield of LGO (Ye et al., 2017). The yield of LGO produced from cellulose catalyzed by solid acid still needs to be improved.

Based on previous research, an important and indispensable step for cellulose

71 pyrolysis to generate LGO was the dehydration reaction (Zhang et al., 2017).

72 Regarding this procedure, it has been reported that both $\mathrm{Fe}_{3} \mathrm{O}_{4}$ and acid catalyst could

73 enhance the dehydration behavior and promote the yield of LGO in catalytic fast 74 pyrolysis cellulose (Lu et al., 2014a; Halpern et al., 1973). In this study, magnetic 
solid acid $\mathrm{Fe}_{3} \mathrm{O}_{4} / \mathrm{C}-\mathrm{SO}_{3} \mathrm{H}_{600}$ was synthesized and applied in catalytic fast pyrolysis of cellulose to produce LGO. Different from previous reported investigations, this research could not only efficiently promote the conversion of cellulose to LGO, but also analyzed its kinetics and reaction mechanism in detail, and investigated the recovery and reuse performance of the catalyst.

\section{Materials and methods}

\section{Materials}

The microcrystalline cellulose, nano- $\mathrm{Fe}_{3} \mathrm{O}_{4}(\geq 99.5 \%, 20 \mathrm{~nm})$ and glucose used in the experiment were purchased from Macklin biochemical Co., Ltd. (Shanghai). $\mathrm{H}_{2} \mathrm{SO}_{4}(99.8 \%)$ was purchased from Guangshi Agent Technology Co., Ltd. (Guangdong). Levoglucosan (LG) (>96\%) and LGO (>96\%) were purchased from Sigma-Aldrich (Shanghai).

\section{Catalyst preparation}

The preparation of the catalyst required two steps: carbonization and sulfonation. Firstly, the nano- $\mathrm{Fe}_{3} \mathrm{O}_{4}(2 \mathrm{~g})$ and glucose $(15 \mathrm{~g})$ were mixed in deionized water (100 $\mathrm{mL})$, and evaporated the water in an oil bath $\left(100{ }^{\circ} \mathrm{C}\right)$ with vigorous stirring to ensure uniform dispersion of the nano- $\mathrm{Fe}_{3} \mathrm{O}_{4}$. After evaporation, the mixture was transferred to a crucible and heated to $500-700^{\circ} \mathrm{C}$ for a period of time in a tube furnace under $\mathrm{N}_{2}$ atmosphere $(240 \mathrm{~mL} / \mathrm{min})$ at a heating rate of $6{ }^{\circ} \mathrm{C} / \mathrm{min}$. The carbonized solid $\mathrm{C} / \mathrm{Fe}_{3} \mathrm{O}_{4}$ therein was taken out and ground through a 200-mesh sieve, and then mixed with $98 \%$ $\mathrm{H}_{2} \mathrm{SO}_{4}$ at a ratio of $1 \mathrm{~g} / 10 \mathrm{~mL}$. After sulfonated in an oil bath for $20 \mathrm{~h}$ at a temperature of $150{ }^{\circ} \mathrm{C}$, the sulfonated catalyst was washed with deionized water until neutral and dried at $105{ }^{\circ} \mathrm{C}$ for $24 \mathrm{~h}$ in an oven finally. The catalysts prepared at $500{ }^{\circ} \mathrm{C}, 600{ }^{\circ} \mathrm{C}$ and $700{ }^{\circ} \mathrm{C}$ were entitled $\mathrm{Fe}_{3} \mathrm{O}_{4} / \mathrm{C}-\mathrm{SO}_{3} \mathrm{H}_{500}, \mathrm{Fe}_{3} \mathrm{O}_{4} / \mathrm{C}-\mathrm{SO}_{3} \mathrm{H}_{600}$ and $\mathrm{Fe}_{3} \mathrm{O}_{4} / \mathrm{C}_{-}-\mathrm{SO}_{3} \mathrm{H}_{700}$, respectively. 


\section{Catalyst characterization}

The X-ray diffraction analysis of the catalyst was carried out in an X'Pert PRO MPD X-ray diffractometer using $\mathrm{Cu} \mathrm{K} \alpha$ radiation source $(\lambda=0.15418 \mathrm{~nm})$. Fourier transform infrared spectroscopy (FTIR, Bruker TENSOR27, Optik Instruments, Brno, Czech Republic) was used to analyze the functional groups contained in the catalyst. Scanning electron microscope (SEM, ZEISS EVO LS10, Cambridge, UK) was used to scan the surface morphology of the catalyst. The acid sites of the catalyst were determined by $\mathrm{NH}_{3}$ temperature programmed desorption $\left(\mathrm{NH}_{3}-\mathrm{TPD}\right.$, Chemisorption analyzer, Quantachrome Instruments, Boynton Beach, FL). Thermogravimetric experiment was carried out in a TG analyzer (SDT650, TA, USA). Sample was put into alumina crucible, and heated from $50{ }^{\circ} \mathrm{C}$ to $650{ }^{\circ} \mathrm{C}$ at the rate of 10,20 and $40{ }^{\circ} \mathrm{C} / \mathrm{min}$.

\section{Kinetic analysis}

The kinetic parameters were obtained by distributed activation energy model (DAEM). It assumed that the thermal decomposition reaction consisted of many simple reactions that obeyed a normal distribution $f(E)$.

$$
f(E) \sim N(E, \sigma)
$$

Due to the existence of the kinetic compensation effect, the activation energy, the pre-reference factor, and the mechanism function were related to each other. Assuming that the pre-reference factor was a constant, the activation energy was only related to the mechanism function, as shown in formula (2).

$$
\alpha=1-\int_{0}^{\infty} \exp \left[-\frac{A}{\beta} \Psi(E, T)\right] f(E) d E
$$

where $\alpha$ is the conversion rate, $\% ; \beta$ is the heating rate, ${ }^{\circ} \mathrm{C} / \mathrm{min} ; E$ is the activation energy, $\mathrm{kJ} / \mathrm{mol} ; \mathrm{A}$ is the pre-exponential factor, $\mathrm{s}^{-1} ; \Psi(E, T)$ is the 
temperature integral:

125

$$
\Psi(E, T)=\int_{0}^{T} \exp \left(\frac{-E}{R T}\right) d T
$$

126

127

128

129

130

131

132

133

134

135

136

137

138

139

140

141

142

143 as follows:

144 Compound yield $(\mathrm{wt} \%)=\frac{\text { mass of compound }}{\text { mass of cellulose }} \times 100 \%$

145 Relative content of compound $(\%)=\frac{\text { Area of a compound }}{\text { Area of all compouds }} \times 100 \%$ 
147

148

149

150

151

152

153

154

155

156

157

158

159

160

161

162

163

164

165

166

167

168

169

170

171

\section{Results and discussion}

Catalyst characterization

The SEM images of the catalysts are shown in Fig. 1. It could be seen that the surface of $\mathrm{Fe}_{3} \mathrm{O}_{4} / \mathrm{C}-\mathrm{SO}_{3} \mathrm{H}_{500}$ and $\mathrm{Fe}_{3} \mathrm{O}_{4} / \mathrm{C}-\mathrm{SO}_{3} \mathrm{H}_{600}$ contained countless pores. This facilitated the contact of the catalysts with cellulose. Although there were many pores on the surface of $\mathrm{Fe}_{3} \mathrm{O}_{4} / \mathrm{C}-\mathrm{SO}_{3} \mathrm{H}_{700}$, it was very messy, probably due to the excessive temperature destroying the pore structure on the surface of $\mathrm{Fe}_{3} \mathrm{O}_{4} / \mathrm{C}-\mathrm{SO}_{3} \mathrm{H}_{700}$. Among the three catalysts, the surface area of $\mathrm{Fe}_{3} \mathrm{O}_{4} / \mathrm{C}-\mathrm{SO}_{3} \mathrm{H}_{500}\left(1.8 \mathrm{~m}^{2} / \mathrm{g}\right)$ was larger than that of $\mathrm{Fe}_{3} \mathrm{O}_{4} / \mathrm{C}-\mathrm{SO}_{3} \mathrm{H}_{600}\left(0.7 \mathrm{~m}^{2} / \mathrm{g}\right)$ and $\mathrm{Fe}_{3} \mathrm{O}_{4} / \mathrm{C}-\mathrm{SO}_{3} \mathrm{H}_{700}\left(0.6 \mathrm{~m}^{2} / \mathrm{g}\right)$ (Table 1). This might be caused by the higher calcination temperature causing $\mathrm{Fe}_{3} \mathrm{O}_{4}$ to be embedded in the pores.

The XRD peaks of the three catalysts were all identified as the crystalline phase of $\mathrm{Fe}_{3} \mathrm{O}_{4}$ (Fig. 2), which indicated that $\mathrm{Fe}_{3} \mathrm{O}_{4}$ remained stable after calcination and sulfonation during the preparation of catalysts. In FTIR analysis, the absorption peak at $598 \mathrm{~cm}^{-1}$ was the $\mathrm{Fe}-\mathrm{O}$ bond vibration in $\mathrm{Fe}_{3} \mathrm{O}_{4}$ (Fig. 3) (Guo et al., 2013). The absorption peaks at $1600-1800 \mathrm{~cm}^{-1}$ were $\mathrm{C}=\mathrm{C}, \mathrm{C}=\mathrm{O}$ and $\mathrm{COO}^{-}$stretching vibrations and $3463 \mathrm{~cm}^{-1}$ was $-\mathrm{OH}$ stretching vibration (Alvaro et al., 2005). The absorption peaks at $1061 \mathrm{~cm}^{-1}\left(-\mathrm{SO}_{3}{ }^{-}\right.$stretching $)$and the $1223 \mathrm{~cm}^{-1}\left(\mathrm{O}=\mathrm{S}=\mathrm{O}\right.$ stretching in $\left.-\mathrm{SO}_{3} \mathrm{H}\right)$ were important signs of the presence of $-\mathrm{SO}_{3} \mathrm{H}$ functional groups (Fukuhara et al., 2011). All peak strengths of $\mathrm{Fe}_{3} \mathrm{O}_{4} / \mathrm{C}-\mathrm{SO}_{3} \mathrm{H}_{500}$ were weak. The difference between $\mathrm{Fe}_{3} \mathrm{O}_{4} / \mathrm{C}-\mathrm{SO}_{3} \mathrm{H}_{600}$ and $\mathrm{Fe}_{3} \mathrm{O}_{4} / \mathrm{C}-\mathrm{SO}_{3} \mathrm{H}_{700}$ was that catalyst $\mathrm{Fe}_{3} \mathrm{O}_{4} / \mathrm{C}-\mathrm{SO}_{3} \mathrm{H}_{600}$ appeared$\mathrm{SO}_{3}{ }^{-}$stretching and $\mathrm{O}=\mathrm{S}=\mathrm{O}$ stretching in $-\mathrm{SO}_{3} \mathrm{H}$ at bands $1061 \mathrm{~cm}^{-1}$ and $1223 \mathrm{~cm}^{-1}$, respectively. This showed the presence of $-\mathrm{SO}_{3} \mathrm{H}$ functional group in $\mathrm{Fe}_{3} \mathrm{O}_{4} / \mathrm{C}$ $\mathrm{SO}_{3} \mathrm{H}_{600} . \mathrm{NH}_{3}$-TPD characterization also indicated that the acid sites of $\mathrm{Fe}_{3} \mathrm{O}_{4} / \mathrm{C}$ $\mathrm{SO}_{3} \mathrm{H}_{600}(0.7 \mathrm{mmol} / \mathrm{g})$ were higher than that of $\mathrm{Fe}_{3} \mathrm{O}_{4} / \mathrm{C}-\mathrm{SO}_{3} \mathrm{H}_{500}(0.1 \mathrm{mmol} / \mathrm{g})$ and 
$172 \mathrm{Fe}_{3} \mathrm{O}_{4} / \mathrm{C}-\mathrm{SO}_{3} \mathrm{H}_{700}(0.5 \mathrm{mmol} / \mathrm{g})$ (Table 1$)$.

173

174

175

176
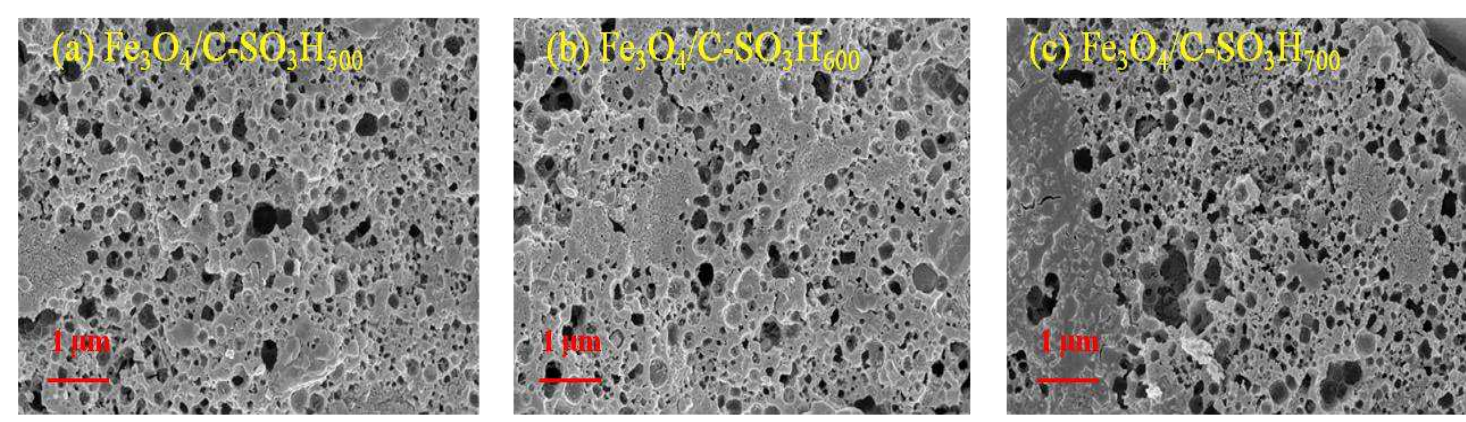

Figure 1. SEM images of catalysts.

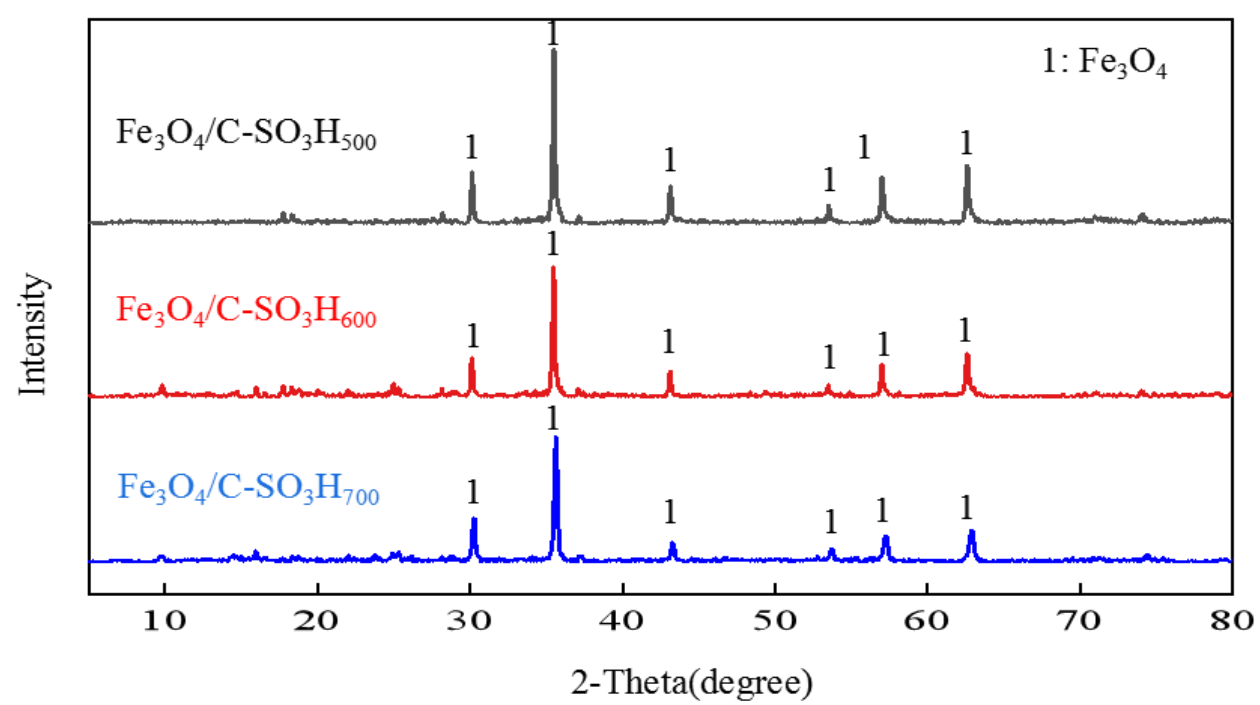

Figure 2. XRD patterns of catalysts.

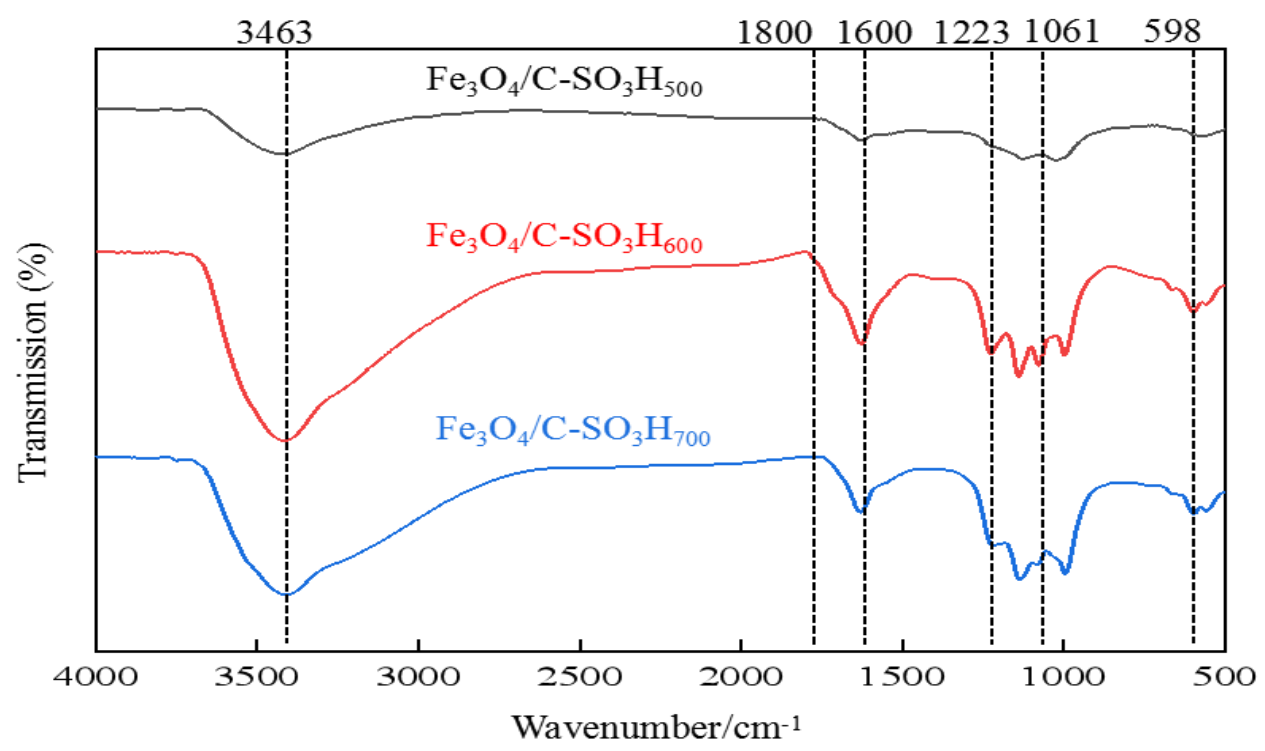

Figure 3. FTIR analysis of catalysts. 
Table 1 . The total acid sites and textural properties of the catalysts

\begin{tabular}{cccc}
\hline Catalysts & $\begin{array}{c}\text { Acid sites } \\
(\mathrm{mmol} / \mathrm{g})\end{array}$ & $\begin{array}{c}\text { BET surface area } \\
\left(\mathrm{m}^{2} / \mathrm{g}\right)\end{array}$ & $\begin{array}{c}\text { Pore volume } \\
\left(\mathrm{cm}^{3} / \mathrm{g}\right)\end{array}$ \\
\hline $\mathrm{Fe}_{3} \mathrm{O}_{4} / \mathrm{C}-\mathrm{SO}_{3} \mathrm{H}_{500}$ & 0.1 & 1.8 & 0.006 \\
$\mathrm{Fe}_{3} \mathrm{O}_{4} / \mathrm{C}-\mathrm{SO}_{3} \mathrm{H}_{600}$ & 0.7 & 0.7 & 0.006 \\
$\mathrm{Fe}_{3} \mathrm{O}_{4} / \mathrm{C}-\mathrm{SO}_{3} \mathrm{H}_{700}$ & 0.5 & 0.6 & 0.002 \\
\hline
\end{tabular}

184

\section{TG and kinetic analysis}

The TG analysis of pure cellulose and cellulose mixed with the solid acid catalyst is shown in Fig. 4 and Table 2. The main weight loss area of cellulose was $300-400{ }^{\circ} \mathrm{C}$, and after mixing with the solid acid, the main weight loss area shifted to 200-400 ${ }^{\circ} \mathrm{C}$. Considering the heating rate was $40{ }^{\circ} \mathrm{C} / \mathrm{min}$, the initial weight loss temperature of cellulose was $335{ }^{\circ} \mathrm{C}$, which was higher than that of cellulose mixed with catalysts $\left(199-263{ }^{\circ} \mathrm{C}\right) . D_{\max }$ was the maximum weight loss rate in the decomposition reaction process, which indicated the degree of the decomposition reaction. The greater the $D_{\max }$ was, the more intense the decomposition reaction revealed. The $D_{\max }$ of cellulose $\left(2.0-2.8 \% /{ }^{\circ} \mathrm{C}\right)$ was also higher than that of cellulose mixed with the solid acid catalysts $\left(0.2-0.7 \% /{ }^{\circ} \mathrm{C}\right)$. The reason was that the thermal stability of cellulose was high, the thermal decomposition was carried out at a higher temperature and the reaction was concentrated, while the thermal stability of cellulose mixed with the catalyst was reduced, resulting in the dispersed decomposition reaction, and the wide main weight loss area.

The DAEM is currently the most accurate thermal analysis kinetic model, which can accurately simulate the experimental curve, as shown in Fig. 5. The kinetic parameters calculated according to DAEM are shown in Table 3. $E$ referred to the global activation energy, that was, the energy that needed to be absorbed when the sample was decomposed. The larger the $E$, the more energy needed to be absorbed 
205 during the decomposition, and the more difficult it was to decompose. $\sigma$ refers to the 206 deviation of activation energy, which indicates the concentration of decomposition 207 reaction. Consider the heating rate was $40{ }^{\circ} \mathrm{C} / \mathrm{min}$, compared with the cellulose mixed 208 with the catalyst $(168.1-175.5 \mathrm{~kJ} / \mathrm{mol})$, the cellulose had the highest activation energy $209(187.4 \mathrm{~kJ} / \mathrm{mol})$. After mixed with the catalyst, activation energy for cellulose 210 decomposition was reduced, thereby reducing the initial decomposition temperature. 211 In addition, the $\sigma$ of cellulose $(0.1 \mathrm{~kJ} / \mathrm{mol})$ was the smallest and the reaction was the 212 most concentrated, while the cellulose mixed with catalyst had larger $\sigma$, and the 213 reaction was dispersed. It could be seen that the thermal stability of cellulose could be 214 destroyed after adding the catalyst, and the cellulose could be decomposed at a lower 215 temperature. 


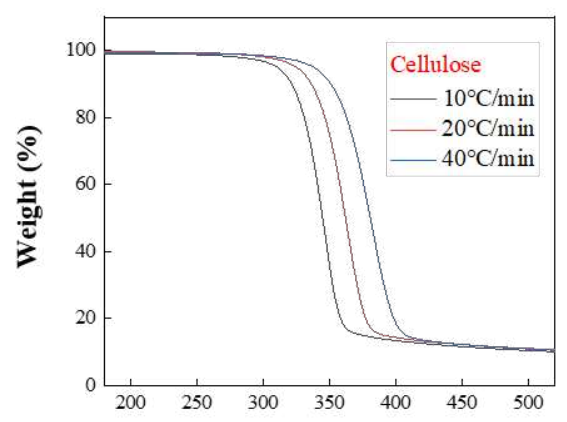

Temperature $\left({ }^{\circ} \mathrm{C}\right.$ )

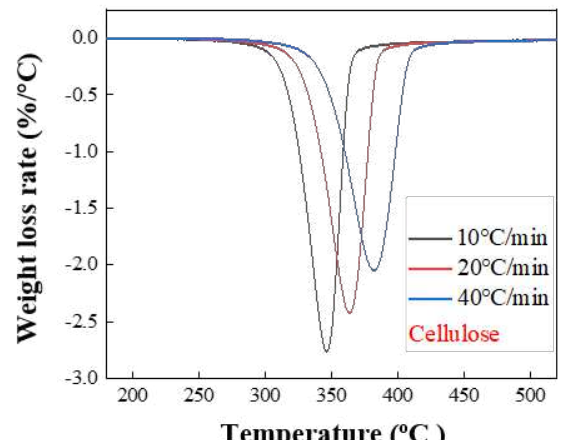

\section{(1)}

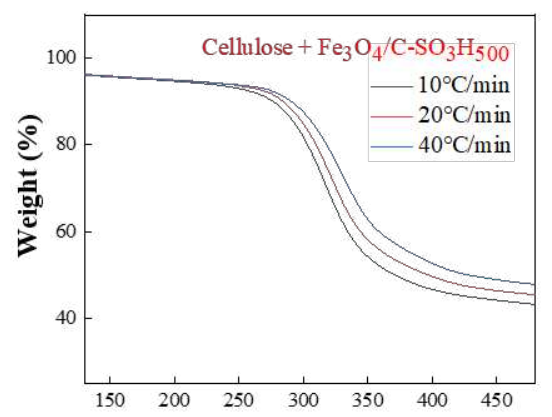

Temperature $\left({ }^{\circ} \mathrm{C}\right)$
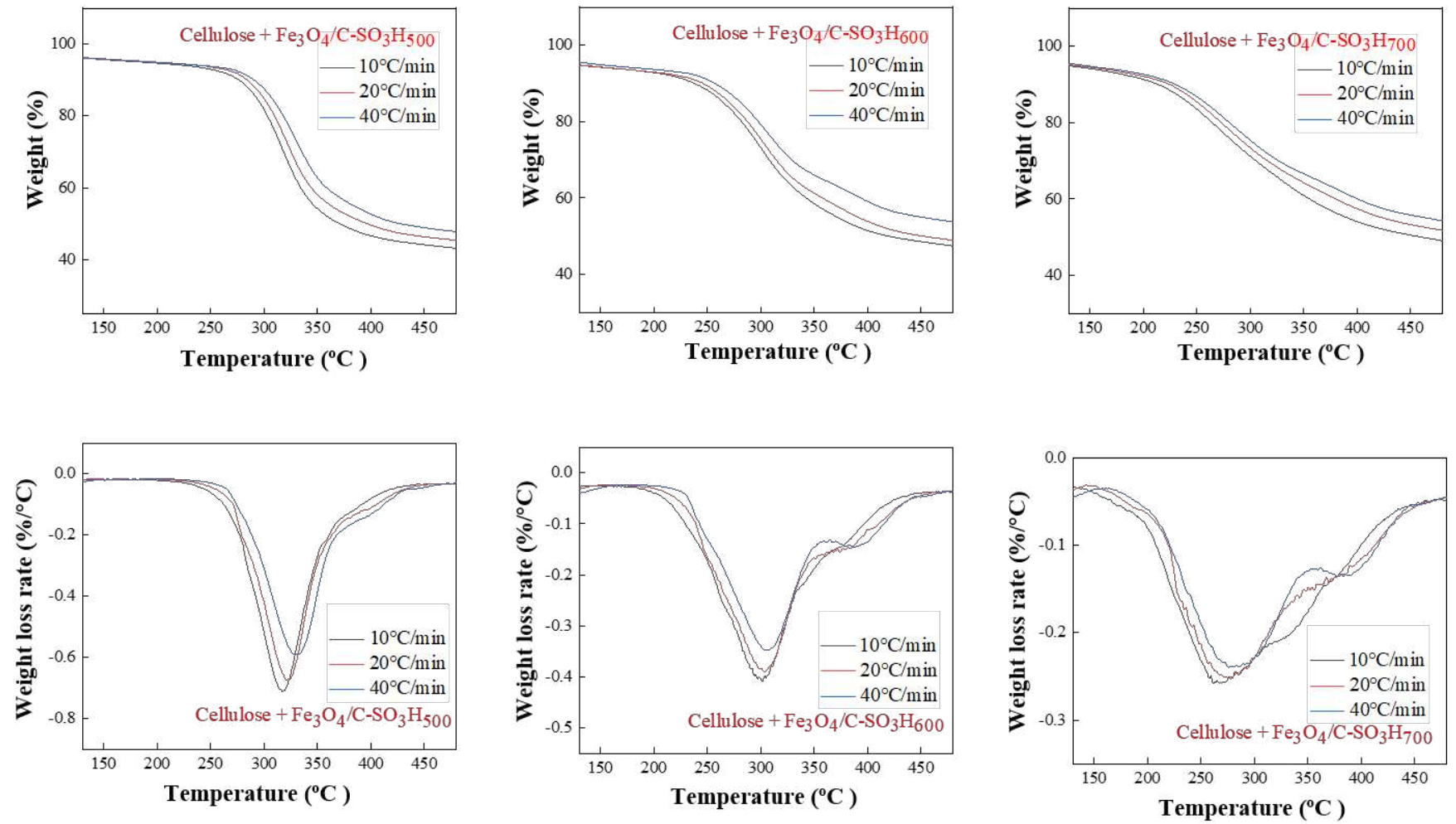

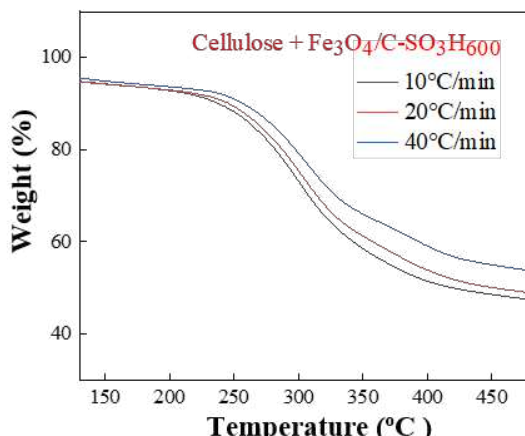

Temperature $\left({ }^{\circ} \mathrm{C}\right.$

Figure 4. TG and DTG curves of cellulose and cellulose mixed with catalyst. 
Table 2. Thermogravimetric parameters at different heating rates

\begin{tabular}{cccccc}
\hline Samples & Heating rates $\left({ }^{\circ} \mathrm{C} / \mathrm{min}\right)$ & $\mathrm{T}_{\mathrm{i}}\left({ }^{\circ} \mathrm{C}\right)$ & $\mathrm{T}_{\mathrm{t}}\left({ }^{\circ} \mathrm{C}\right)$ & $\mathrm{T}_{\max }\left({ }^{\circ} \mathrm{C}\right)$ & $\mathrm{D}_{\max }\left(\% /{ }^{\circ} \mathrm{C}\right)$ \\
\hline \multirow{2}{*}{ Cellulose } & 10 & 308 & 368 & 346 & -2.8 \\
& 20 & 322 & 383 & 363 & -2.4 \\
& 40 & 335 & 403 & 381 & -2.0 \\
\hline Cellulose $+\mathrm{Fe}_{3} \mathrm{O}_{4} /{\mathrm{C}-\mathrm{SO}_{3} \mathrm{H}_{500}}$ & 10 & 250 & 413 & 317 & -0.7 \\
& 20 & 257 & 419 & 323 & -0.7 \\
\hline & 40 & 263 & 425 & 329 & -0.6 \\
\hline \multirow{3}{*}{ Cellulose $+\mathrm{Fe}_{3} \mathrm{O}_{4} / \mathrm{C}-\mathrm{SO}_{3} \mathrm{H}_{600}$} & 10 & 218 & 424 & 300 & -0.4 \\
& 20 & 225 & 430 & 304 & -0.4 \\
& 40 & 227 & 434 & 307 & -0.3 \\
\hline
\end{tabular}

$\mathrm{T}_{\mathrm{i}}$ is the temperature of pyrolysis at which the main weightless zone begins, $5 \%$.

$T_{t}$ is the temperature of pyrolysis at which the main weightless zone finishes, $95 \%$.

$\mathrm{T}_{\max }$ is the temperature corresponding to the highest point of the DTG peak.

$\mathrm{D}_{\max }$ is the weight loss rate corresponding to the highest point of the DTG peak. 

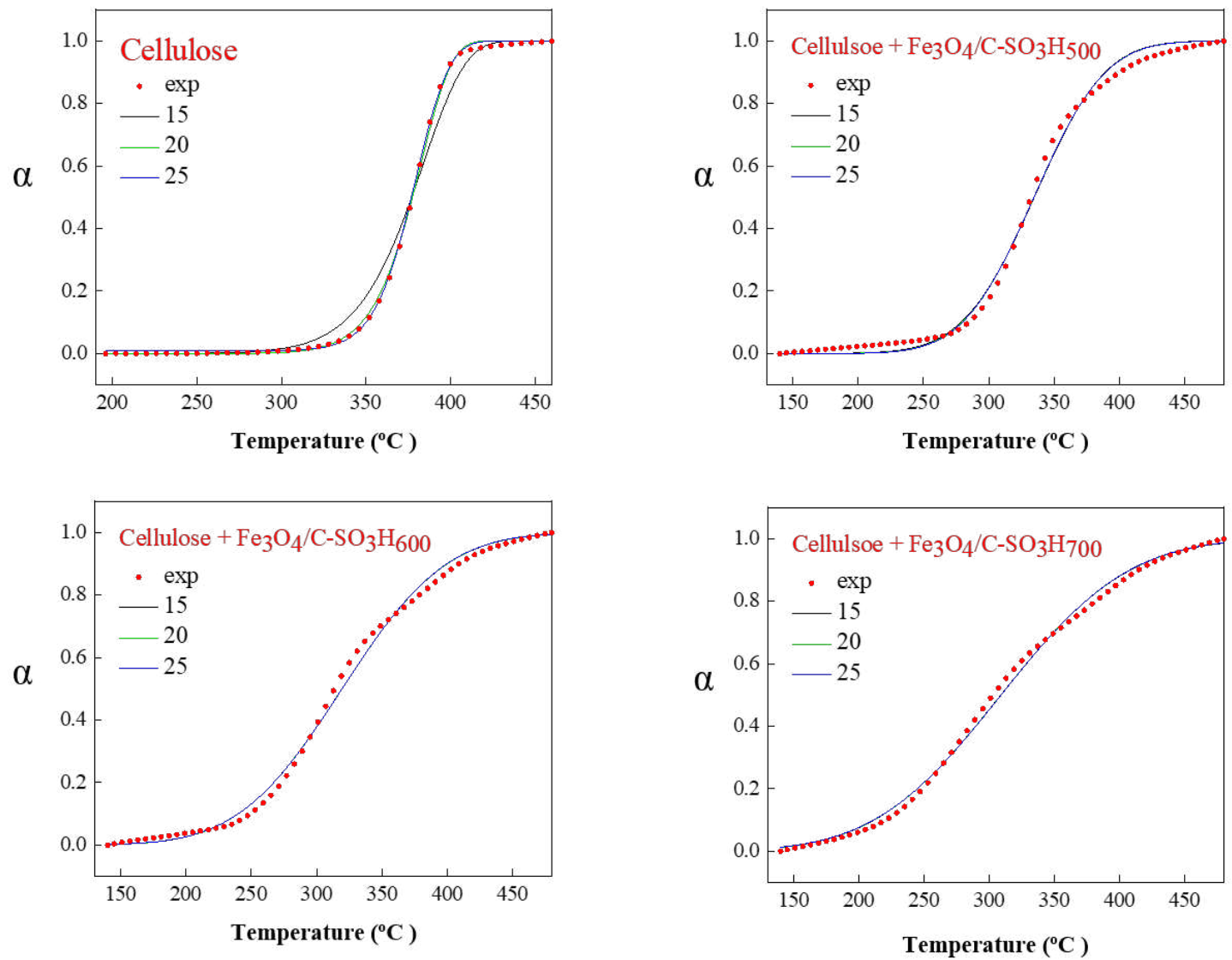

Figure 5. The experimental curve and curve fitted by DAEM model. 
Table 3. Kinetic parameters on the basis of the distributed activation energy model

\begin{tabular}{|c|c|c|c|c|c|c|}
\hline Samples & $\lg \mathrm{A}\left(\mathrm{s}^{-1}\right)$ & $E(\mathrm{~kJ} / \mathrm{mol})$ & $\sigma(\mathrm{kJ} / \mathrm{mol})$ & $\mathrm{R}^{2}$ & Compensation effec & \\
\hline \multirow{3}{*}{ Cellulose } & 15 & 187.4 & 0.1 & 0.9992 & \multirow{3}{*}{$E=5.1915 \ln A+8.0246$} & \multirow{3}{*}{$\mathrm{R}^{2}=1$} \\
\hline & 20 & 246.9 & 3.6 & 0.9996 & & \\
\hline & 25 & 307.0 & 6.1 & 0.9994 & & \\
\hline \multirow{3}{*}{ Cellulose $+\mathrm{Fe}_{3} \mathrm{O}_{4} / \mathrm{C}-\mathrm{SO}_{3} \mathrm{H}_{500}$} & 15 & 175.5 & 11.3 & 0.9963 & \multirow{3}{*}{$E=4.8464 \ln A+8.0474$} & \multirow{3}{*}{$\mathrm{R}^{2}=1$} \\
\hline & 20 & 231.1 & 15.5 & 0.9964 & & \\
\hline & 25 & 287.1 & 19.6 & 0.9964 & & \\
\hline \multirow{3}{*}{ Cellulose $+\mathrm{Fe}_{3} \mathrm{O}_{4} / \mathrm{C}-\mathrm{SO}_{3} \mathrm{H}_{600}$} & 15 & 171.1 & 17.6 & 0.9967 & \multirow{3}{*}{$\mathrm{E}=4.7249 \ln \mathrm{A}+7.8654$} & \multirow{3}{*}{$\mathrm{R}^{2}=1$} \\
\hline & 20 & 225.3 & 23.5 & 0.9967 & & \\
\hline & 25 & 279.9 & 29.4 & 0.9967 & & \\
\hline \multirow{3}{*}{ Cellulose $+\mathrm{Fe}_{3} \mathrm{O}_{4} / \mathrm{C}-\mathrm{SO}_{3} \mathrm{H}_{700}$} & 15 & 168.1 & 22.0 & 0.9975 & \multirow{3}{*}{$E=4.6415 \ln A+7.6873$} & \multirow{3}{*}{$\mathrm{R}^{2}=1$} \\
\hline & 20 & 221.3 & 29.2 & 0.9975 & & \\
\hline & 25 & 275.0 & 36.3 & 0.9974 & & \\
\hline
\end{tabular}




\section{Effect of different catalysts on the yield of LGO}

The yield of LGO prepared by fast pyrolysis of pure cellulose and fast pyrolysis of cellulose catalyzed by different catalysts was shown in Fig. 6. The yield and relative content of LG were also analyzed as it was the main product in non-catalytic pyrolysis of cellulose. During the non-catalytic pyrolysis of pure cellulose, the yield and relative content of LG were as high as $38.6 \mathrm{wt} \%$ and $84.3 \%$, respectively, while the yield $(0.3 \mathrm{wt} \%)$ and relative content $(0.9 \%)$ of LGO in the pyrolysis products were very low. In catalytic pyrolysis of cellulose, both the yield and relative content of LG decreased significantly. It could be seen from the different cellulose pyrolysis results that there was a significant negative correlation between the production of LG and LGO, which should be further analyzed. The higher the yield and relative content of LGO was, the more obvious the decrease in the yield and relative content of LG obtained. $\mathrm{Fe}_{3} \mathrm{O}_{4}$ and acidic sites $-\mathrm{SO}_{3} \mathrm{H}$ enhanced the dehydration behavior in the cellulose pyrolysis process, which was the main reason for the improvement in LGO yield. The yield of LGO (20.0 wt\%) in the pyrolysis product was obtained from cellulose catalyzed by $\mathrm{Fe}_{3} \mathrm{O}_{4} / \mathrm{C}-\mathrm{SO}_{3} \mathrm{H}_{600}$, which was higher than that from cellulose catalyzed by $\mathrm{Fe}_{3} \mathrm{O}_{4} / \mathrm{C}-\mathrm{SO}_{3} \mathrm{H}_{500}(4.2 \mathrm{wt} \%)$ and $\mathrm{Fe}_{3} \mathrm{O}_{4} / \mathrm{C}-\mathrm{SO}_{3} \mathrm{H}_{700}$ (13.5 wt $\%$ ). The functional groups and acidic sites in the catalyst were the keys to promoting the formation of $\mathrm{LGO} . \mathrm{Fe}_{3} \mathrm{O}_{4} / \mathrm{C}-\mathrm{SO}_{3} \mathrm{H}_{500}$ had fewer functional groups and acidic sites, causing the poor catalytic effect. $\mathrm{Fe}_{3} \mathrm{O}_{4} / \mathrm{C}-\mathrm{SO}_{3} \mathrm{H}_{600}$ exhibited more $-\mathrm{SO}_{3} \mathrm{H}$ functional groups than $\mathrm{Fe}_{3} \mathrm{O}_{4} / \mathrm{C}-\mathrm{SO}_{3} \mathrm{H}_{700}$. Furthermore, $\mathrm{Fe}_{3} \mathrm{O}_{4} / \mathrm{C}-\mathrm{SO}_{3} \mathrm{H}_{600}$ had the highest acidic site, which might also an important factor to promote the formation of $\mathrm{LGO}$. $\mathrm{Fe}_{3} \mathrm{O}_{4} / \mathrm{C}$ $\mathrm{SO}_{3} \mathrm{H}_{600}$ had the best catalytic effect, and its reaction condition was further optimized. 

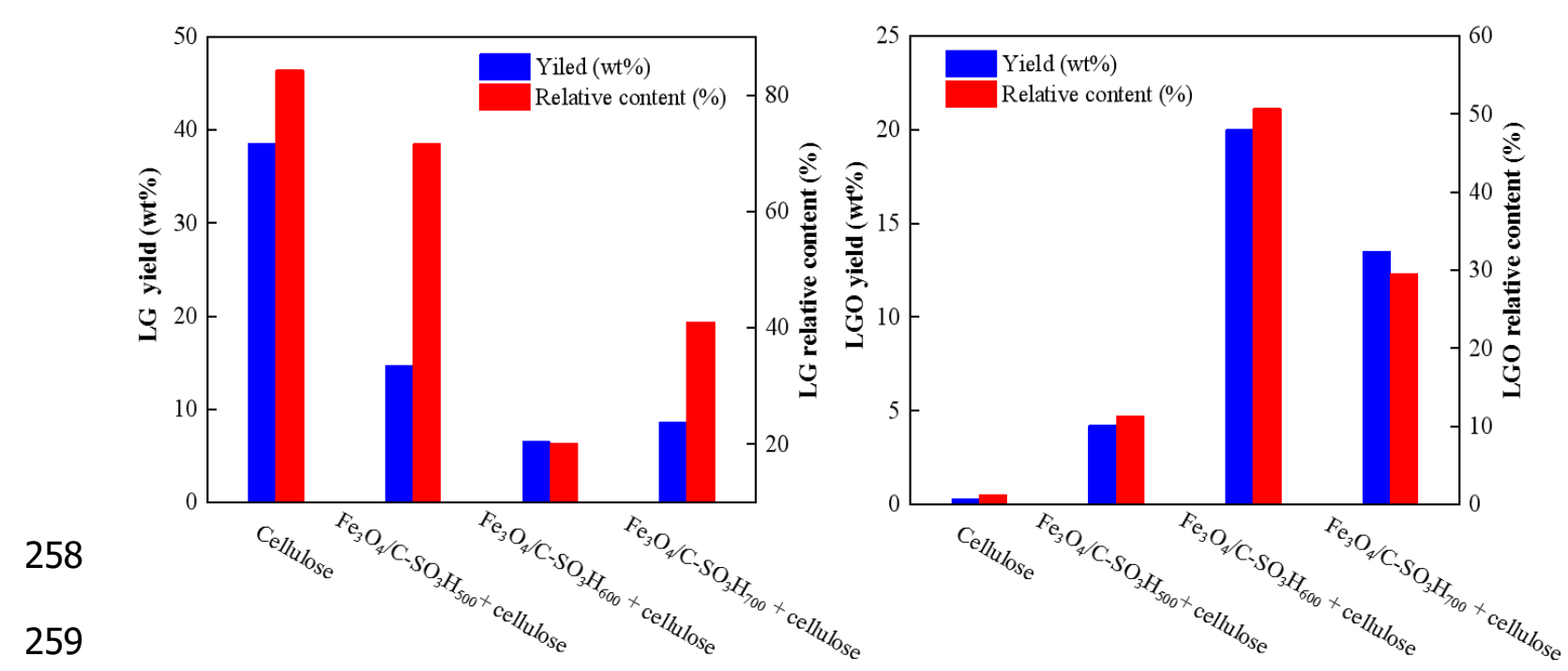

Figure 6. The effect of three catalysts to pyrolyze cellulose on the yield and relative content of LG and LGO.

\section{Effects of the catalytic pyrolysis temperature on the yield of LGO}

The distribution of pyrolysis products could vary with temperature as the dominant reaction pathways shifted in rate and overall extent (Maduskar et al., 2018).

Fig. 7 shows the yield and relative content of LG and LGO at different temperatures during non-catalytic and catalytic pyrolysis. As the temperature increased, the cellulose was fully depolymerized and accompanied by a series of competitive reactions. The yield of LG increased from $38.6 \mathrm{wt} \%$ to $60.1 \mathrm{wt} \%$ as the temperature

271 increased from $300{ }^{\circ} \mathrm{C}$ to $500{ }^{\circ} \mathrm{C}$, while the yield of LGO $(0.2 \mathrm{wt} \%-0.3 \mathrm{wt} \%)$ was very low. As depicted in Fig. 8a, LG and 1,6-anhydro-.beta.-D-glucofuranose (AGF) were the main products obtained by non-catalytic fast pyrolysis of cellulose at $300{ }^{\circ} \mathrm{C}$, with relative content of $79 \%$ and $8 \%$, respectively. As the temperature rose from $300{ }^{\circ} \mathrm{C}$ to $500{ }^{\circ} \mathrm{C}$ under non-catalytic pyrolysis conditions, the main products of 276 cellulose pyrolysis were still LG and AGF, but hydroxyacetaldehyde (HAA), furfural 277 (FF), 5-hydromethyl-furfural (5-HMF) and other compounds were also produced. 278 Although the increase in temperature was accompanied by a series of competitive 279 reactions that led to a decrease in the relative content of $L G$, the increase in 
temperature also made the cellulose fully depolymerized resulting in the increasing yield of LG.

The catalytic pyrolysis of cellulose with $\mathrm{Fe}_{3} \mathrm{O}_{4} / \mathrm{C}-\mathrm{SO}_{3} \mathrm{H}_{600}$ could promote the formation of LGO and inhibit the formation of LG and AGF. The increase in the yield of LGO might be caused by the catalytic dehydration of LG. The promotion on LGO production was more obvious at $300{ }^{\circ} \mathrm{C}$. According to Fig. 8 b, it could be seen that the primary pyrolysis product of catalytic fast pyrolysis of cellulose at $300{ }^{\circ} \mathrm{C}$ was transformed from LG to LGO, accompanied by a certain amount of 1,4:3,6dianhydro- $\alpha$-d-glucopyranose (DGP). During catalytic pyrolysis, the LGO yield tended to increase at $250-300{ }^{\circ} \mathrm{C}$ and then decrease at $300-500{ }^{\circ} \mathrm{C}$. The highest yield of LGO (20.0 wt\%) was obtained at $300{ }^{\circ} \mathrm{C}$ and the lowest LGO yield was got at $500{ }^{\circ} \mathrm{C}(4.9 \mathrm{wt} \%)$. The relative content of LGO also increased at $250-300{ }^{\circ} \mathrm{C}$, and then decreased at $300-500{ }^{\circ} \mathrm{C}$. The low yield and relative content of LGO at $250{ }^{\circ} \mathrm{C}$ could be attributed to the incomplete decomposition of cellulose and the difficulty in providing enough heat to enable the $\mathrm{Fe}_{3} \mathrm{O}_{4} / \mathrm{C}-\mathrm{SO}_{3} \mathrm{H}_{600}$ to catalyze the dehydration of cellulose. Catalytic fast pyrolysis could effectively reduce the competitive reaction in the cellulose pyrolysis process at $500{ }^{\circ} \mathrm{C}$, and make the product distribution concentrate on the anhydrosugars LG, LGO, and DGP (Fig. 8d). The formation of LGO was mainly through glycosidic bond cleavage reactions in which cellulose was 299 depolymerized and then exposed on dehydration reactions of the pyran ring. The 300 dehydration process was the main reactions that affected the formation of LGO, 301 mainly occurred at low temperatures, and the cleavage of glycosidic bonds mainly 302 occurred in the medium temperature. As the pyrolysis temperature increased, the rate 303 of cellulose glycosidic bond cleavage reaction was accelerated. When it was faster 304 than the dehydration rate, only a small part of the glycosidic bond cleavage product 

of LGO production at $300-500{ }^{\circ} \mathrm{C}$ in catalytic pyrolysis. These results also

307 demonstrated that $\mathrm{Fe}_{3} \mathrm{O}_{4} / \mathrm{C}-\mathrm{SO}_{3} \mathrm{H}_{600}$ could not only promote the formation of LGO,

308 but also reduced the pyrolysis temperature of cellulose.
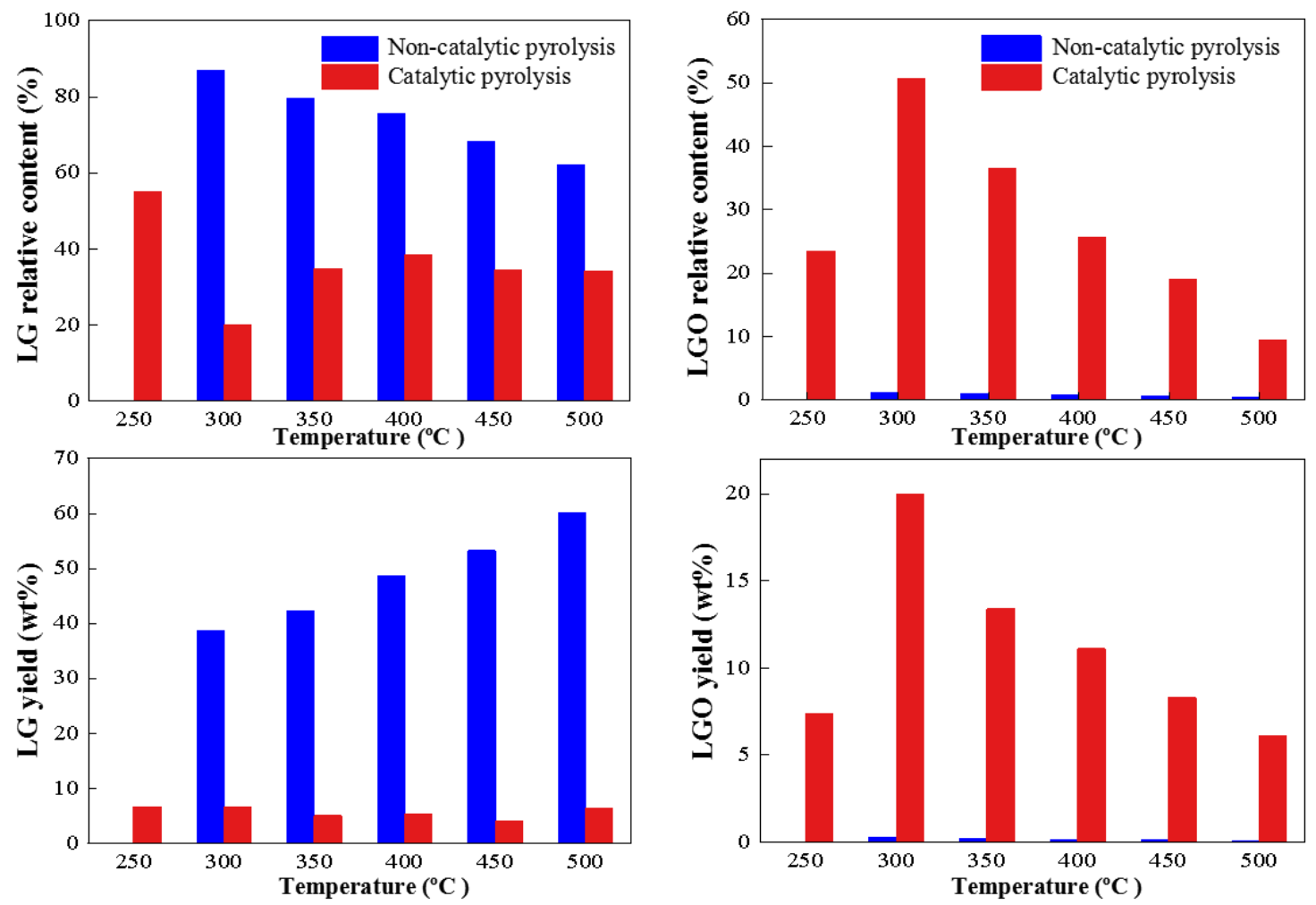

Figure 7. Effect of the temperature on the relative content and yield of LG and LGO. 

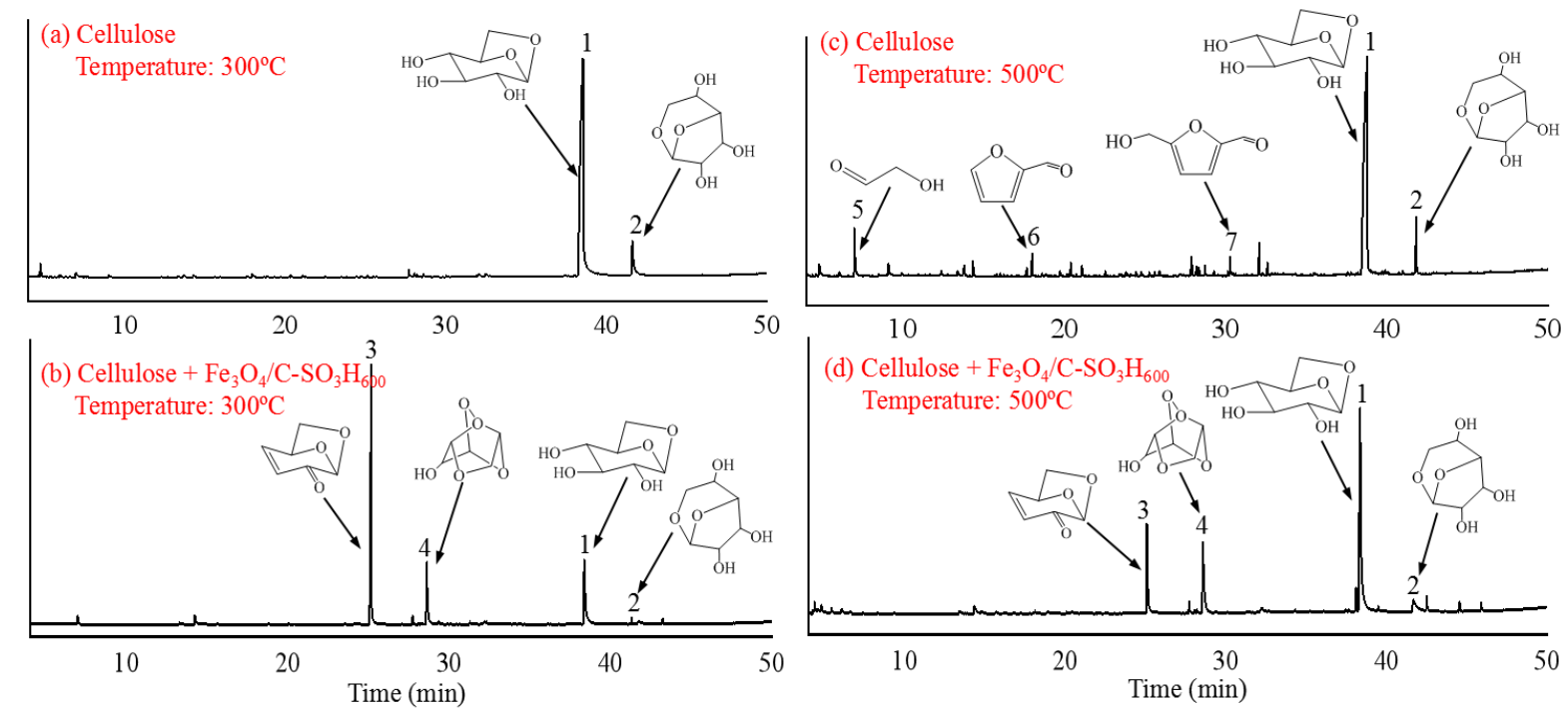

Figure 8. Typical ion chromatograms of cellulose pyrolysis: (a) cellulose in noncatalytic pyrolysis at $300{ }^{\circ} \mathrm{C}$, (b) cellulose in catalytic pyrolysis at $300{ }^{\circ} \mathrm{C}$, (c) cellulose in noncatalytic pyrolysis at $500{ }^{\circ} \mathrm{C}$, (d) cellulose in catalytic pyrolysis at $500{ }^{\circ} \mathrm{C}$, (1) LG, (2) AGF, (3) LGO, (4) DGP, (5) HAA, (6) FF, (7) 5-HMF.

\section{Effect of the $\mathrm{Fe}_{3} \mathrm{O}_{4} / \mathrm{C}-\mathrm{SO}_{3} \mathrm{H}_{600}$ to cellulose ratio}

The ratio of $\mathrm{Fe}_{3} \mathrm{O}_{4} / \mathrm{C}-\mathrm{SO}_{3} \mathrm{H}_{600}$ to cellulose is also an important factor affecting decrease, while the yield and relative content of LG continued to decrease as the amount of catalyst increased (Fig. 9). This showed that when the amount of catalyst was increased, the conversion of LG to LGO was promoted. The best ratio of $\mathrm{Fe}_{3} \mathrm{O}_{4} / \mathrm{C}-\mathrm{SO}_{3} \mathrm{H}_{600}$ to cellulose was $1: 1$, in which the yield and relative content of LGO were $20.0 \mathrm{wt} \%$ and $50.7 \%$, respectively. When the ratio of $\mathrm{Fe}_{3} \mathrm{O}_{4} / \mathrm{C}-\mathrm{SO}_{3} \mathrm{H}_{600}$ to cellulose rose from 1:3 to $1: 1$, the acidic sites of the catalyst gradually increased, and the cellulose was able to completely contact the catalyst, so the yield of LGO

331 continued to rise. When the ratio of $\mathrm{Fe}_{3} \mathrm{O}_{4} / \mathrm{C}-\mathrm{SO}_{3} \mathrm{H}_{600}$ to cellulose increased from 1:1 to $3: 1$, the relative content of LGO changed a little, but the yield of LGO decreased to

$33312.6 \mathrm{wt} \%$, which indicated that the excess catalyst exhibited a negative effect on the 334 yield of LGO. The conclusion could be depicted as: first, an excessive amount of 
catalyst would increase the heat transfer resistance of the sample, making it difficult for heat energy to accurately act on the catalytic reaction, thereby weakening the catalytic effect (Mullen and Boateng, 2010). Second, dehydration and charring reactions of cellulose were boosted by excessive catalyst, resulting in the reduction of organic volatile products (Branca et al., 2011). In addition, excess catalyst might also catalyze further reactions of LGO, leading to reduction in LGO yield (Bai et al., 2019).

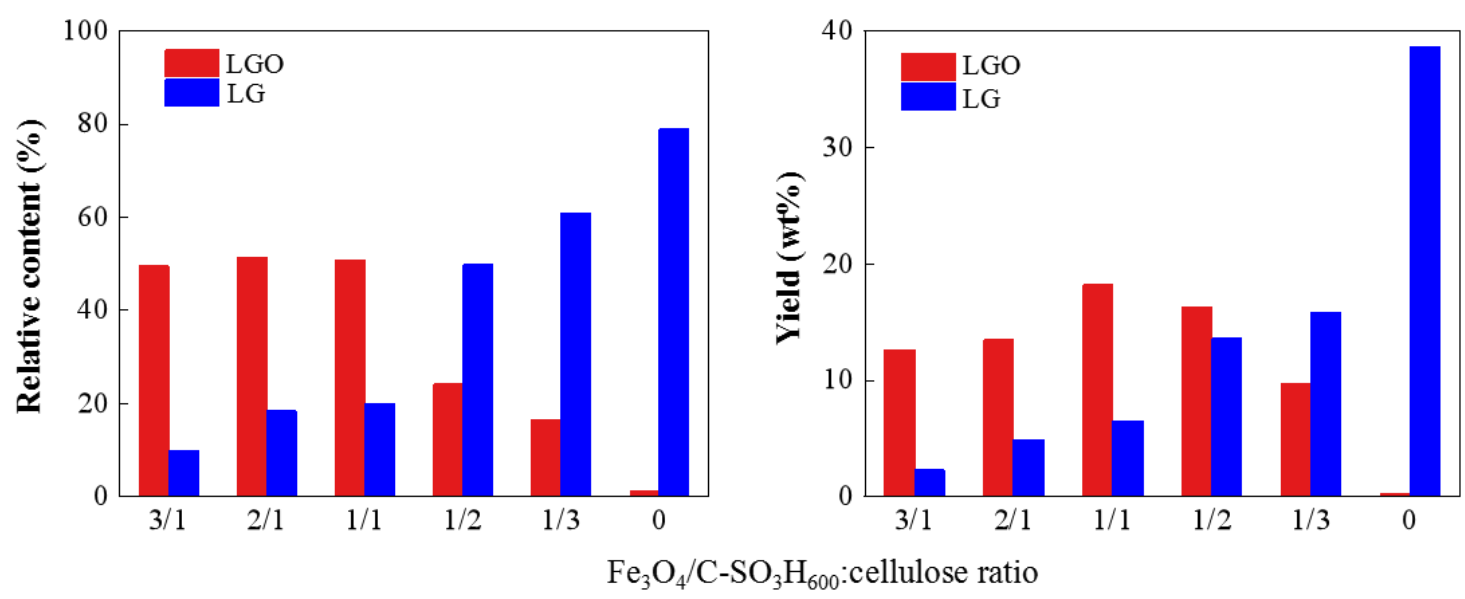

Figure 9. Effect of $\mathrm{Fe}_{3} \mathrm{O}_{4} / \mathrm{C}-\mathrm{SO}_{3} \mathrm{H}_{600}$-to-cellulose ratio on the relative content and

Recycling of the catalyst

In order to evaluate the stability of the catalyst, the reuse of $\mathrm{Fe}_{3} \mathrm{O}_{4} / \mathrm{C}-\mathrm{SO}_{3} \mathrm{H}_{600}$ for LGO production was repeatedly conducted under the optimum conditions of $300{ }^{\circ} \mathrm{C}$ 348 and the ratio of cellulose to catalyst of 1:1. As shown in Fig. 10, the yields of LGO in 349 the three cycle experiments were $14.1 \mathrm{wt} \%, 11.6 \mathrm{wt} \%$, and $8.3 \mathrm{wt} \%$, respectively. 350 This showed that the catalyst could still effectively increase the yield of LGO in the 351 cellulose pyrolysis product after undergoing the cycle experiment, but the acid sites in 352 the catalyst might fall off during multiple cycles, so the catalyst effect of catalyst was 353 significantly reduced. To improve the circulated feasibility the catalyst, the three354 cycled catalyst was mixed with $\mathrm{H}_{2} \mathrm{SO}_{4}$ and sulfonated at $150{ }^{\circ} \mathrm{C}$ for $20 \mathrm{~h}$ for regeneration. The results of fast pyrolysis showed that the catalytic activity of the 
regenerated catalyst was completely restored, and the yield of LGO reached $20.6 \mathrm{wt} \%$.

357 Compared with catalysts such as liquid acids and ionic liquids, $\mathrm{Fe}_{3} \mathrm{O}_{4} / \mathrm{C}-\mathrm{SO}_{3} \mathrm{H}_{600}$ 358 could not only efficiently catalyze the production of LGO from cellulose, but also 359 could be recycled and reused, which was more economical and practical.

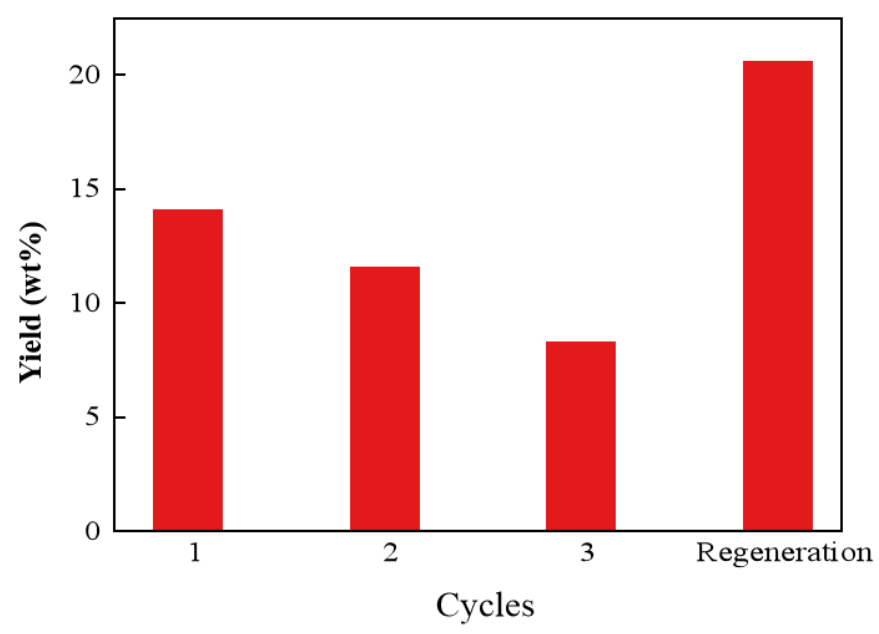

Figure 10. Effect of catalyst cycle on LGO yield at $300{ }^{\circ} \mathrm{C}$.

\section{The mechanism of fast pyrolysis of cellulose to LGO}

According to currently proposed views, there were two main ways to produce LGO. First, cellulose was pyrolyzed and depolymerized to produce LG, and LG was further dehydrated to produce LGO. Second, cellulose was first dehydrated during pyrolysis, and then the glycoside bonds at both ends were broken to form LGO (Zhang et al., 2017; Lu et al., 2011). The latter process did not produce LG. In this experiment, since the increase in LGO yield was consistent with the decrease in LG yield, it was speculated that $\mathrm{Fe}_{3} \mathrm{O}_{4} / \mathrm{C}-\mathrm{SO}_{3} \mathrm{H}_{600}$ could promote further dehydration of LG to produce LGO. To verify it, pure $\mathrm{LG}$ was mixed with $\mathrm{Fe}_{3} \mathrm{O}_{4} / \mathrm{C}-\mathrm{SO}_{3} \mathrm{H}_{600}$ for fast pyrolysis at $300{ }^{\circ} \mathrm{C}$. The typical ion chromatogram was shown in Fig. 11. The results showed that the presence of $\mathrm{Fe}_{3} \mathrm{O}_{4} / \mathrm{C}-\mathrm{SO}_{3} \mathrm{H}_{600}$ could indeed catalyze the dehydration of LG to produce LGO and DGP. It is noticeable that although LGO and DGP were both products of LG's further dehydration, the increase in the yield of LGO was 
significantly more than that of DGP. This showed that the catalytic effect of $\mathrm{Fe}_{3} \mathrm{O}_{4} / \mathrm{C}-$

$376 \mathrm{SO}_{3} \mathrm{H}_{600}$ was also selective. After observing the chemical structure of the three

377 anhydrosugars, it could be found that LG and LGO had similar bicyclic structures

378 (1,5- and 1,6-acetal rings). The conversion of LG to LGO only required dehydration

379 to form $\mathrm{C}_{2}$ carbonyl and $\mathrm{C}_{3}=\mathrm{C}_{4}$ bonds. The conversion from LG to DGP initially 380 requires intramolecular transglycosylation to form 1,4-anhydride, and then 381 etherification to form 3,6-anhydride (Shafizadeh et al., 1978). The latter was more 382 complicated. This explained that $\mathrm{Fe}_{3} \mathrm{O}_{4} / \mathrm{C}-\mathrm{SO}_{3} \mathrm{H}_{600}$ selectively catalyzed the 383 dehydration of LG to LGO instead of DGP during the pyrolysis of cellulose. A 384 possible pathway for the production of LGO by catalytic pyrolysis of cellulose was 385 presented in Fig. 12. First, cellulose broke the glycosidic bonds on both sides by 386 thermal pyrolysis to produce LG. Then LG was further dehydrated under acid 387 catalysis to generate LGO. In this procedure, S1 with the carbon-carbon double bonds 388 was produced through 3-OH obtained H ( $\mathrm{Lu}$ et al., 2014b). Acid catalysis caused this 389 reaction and promoted its dehydration. Then a keto-enol tautomerism reaction 390 occurred to form a carbon-oxygen double bonds (S2). After these conversions were 391 completed, acid catalysis caused $\mathrm{S} 2$ to lose another molecule of $\mathrm{H}_{2} \mathrm{O}$ to produce LGO. 

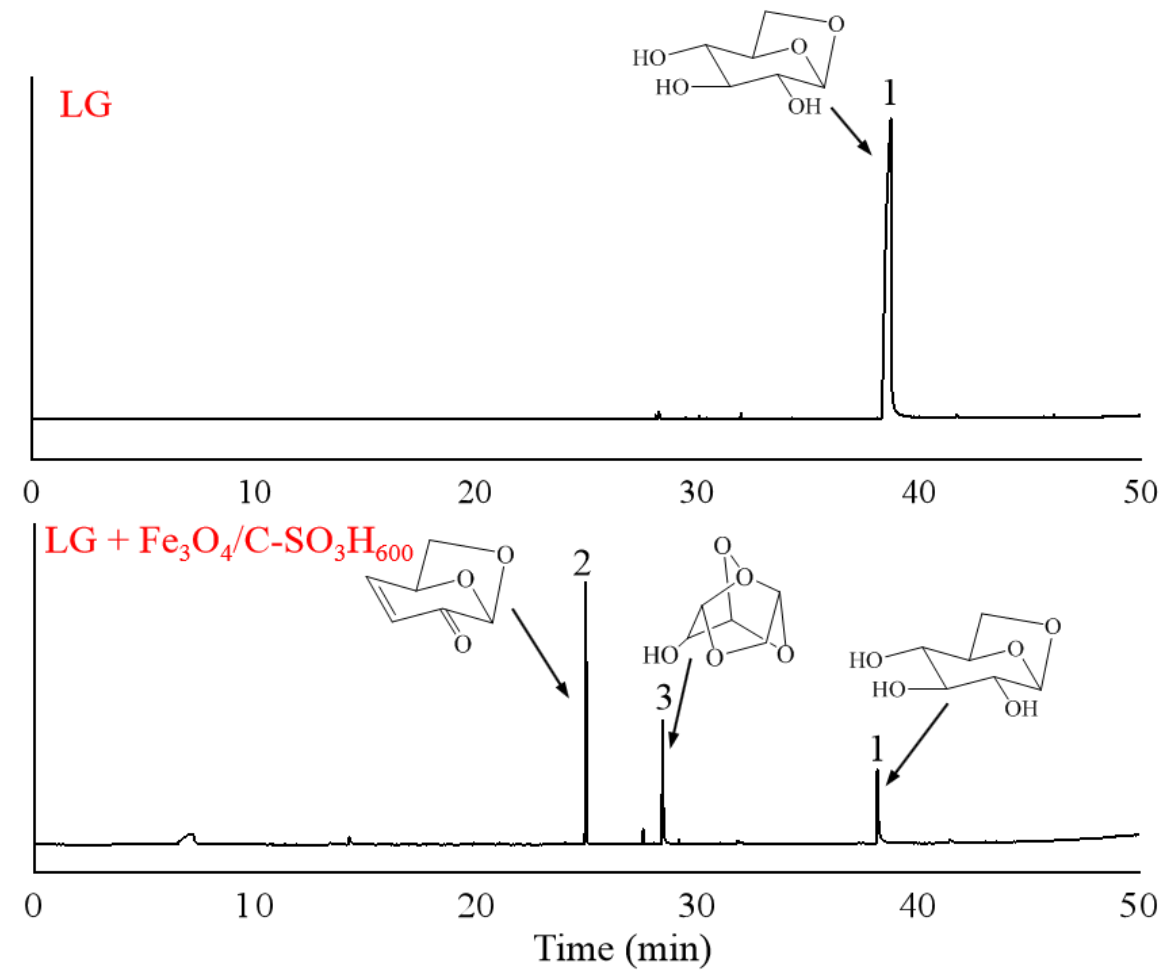

Figure 11. Typical ion chromatograms of LG in noncatalytic and catalytic pyrolysis: (1) LG, (2) LGO, (3) DGP.
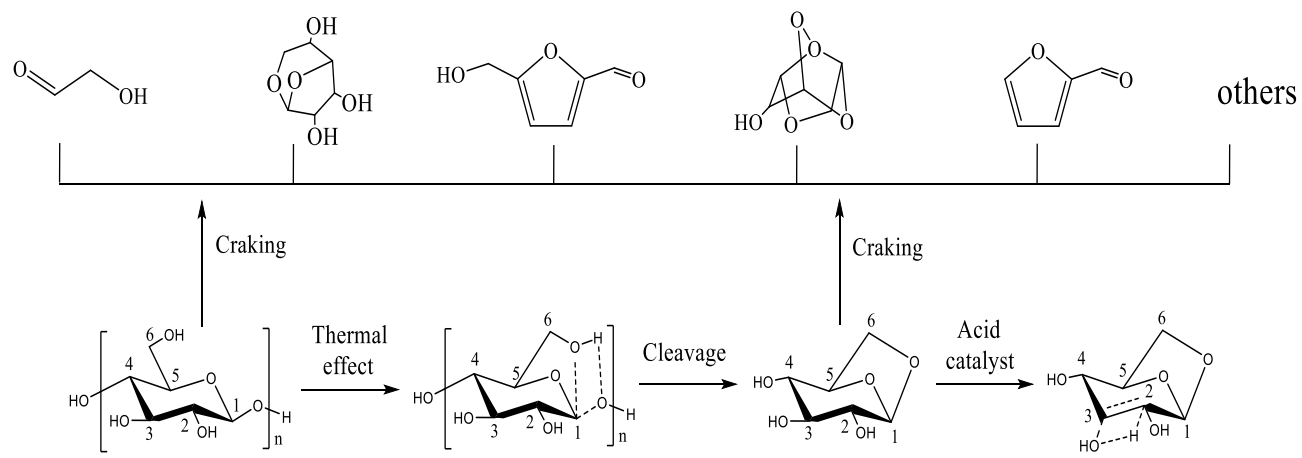

Cellulose

LG
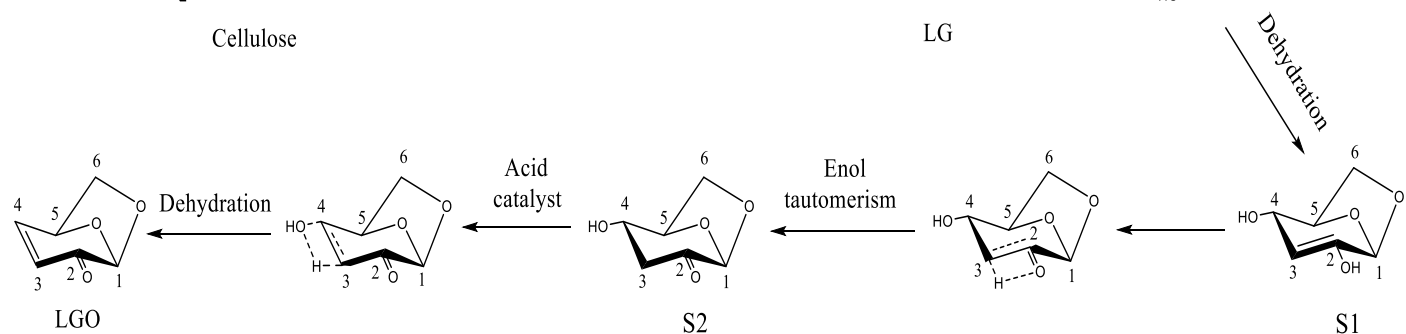

S1

Figure 12. Possible reaction mechanism of catalytic fast pyrolysis of cellulose for LG and LGO production. 


\section{Conclusions}

Magnetic solid acid $\mathrm{Fe}_{3} \mathrm{O}_{4} / \mathrm{C}-\mathrm{SO}_{3} \mathrm{H}_{600}$ was prepared to catalyze fast pyrolysis of cellulose for the selective production of LGO. The yield of LGO was increased from $0.3 \mathrm{wt} \%$ to $20.0 \mathrm{wt} \%$ at a pyrolysis temperature of $300{ }^{\circ} \mathrm{C}$. The catalytic pyrolysis of cellulose could not only reduce the reaction-required temperature and promote the LGO production, but also could be reused for recycling in an economical and practical approach. In addition, this study explored the mechanism of cellulosic pyrolysis to produce LGO, indicating that LGO could be produced via further dehydration of LG.

\section{Declarations}

Not applicable.

\section{Funding}

This work was funded by the National Natural Science Foundation of China (No. 51606204), the Science and Technology Planning Project of Guangzhou city and Guangdong province (No. 2017A020216007, 201707010236).

\section{Conflict of Interest}

The authors declare that they have no conflict of interest.

\section{References}

Alvaro M, Corma A, Das D, Fornes V, Garcia, H (2005) "Nafion"-functionalized mesoporous MCM41 silica shows high activity and selectivity for carboxylic acid esterification and Friedel-Crafts acylation reactions. J Catal 231(1):48-55. https://doi.org/10.1016/j.jcat.2005.01.007.

Bai XW, Li J, Jia CX, Shao JA, Yang Q, Chen YQ, Yang HP, Wang XH, Chen HP (2019) Preparation of furfural by catalytic pyrolysis of cellulose based on nano $\mathrm{Na} / \mathrm{Fe}$-solid acid. Fuel 258:116089. https://doi.org/10.1016/j.fuel.2019.116089.

Branca C, Galgano A, Blasi C, Esposito M, Blasi CD (2011) $\mathrm{H}_{2} \mathrm{SO}_{4}$-catalyzed pyrolysis of corncobs. Energy Fuels 25(1):359-369. https://doi.org/10.1021/ ef101317f.

Cao F, Schwartz TJ, McClelland DJ., Krishna SH, Dumesic JA, Huber GW (2015) Dehydration of cellulose to levoglucosenone using polar aprotic solvents. Energy Environ Sci 8(6):1808-1815. https://doi.org/10.1039/c5ee00353a.

Dobele G, Rossinskaja G, Telysheva G, Meier D, Faix O (1999) Cellulose dehydration and depolymerization reactions during pyrolysis in the presence of phosphoric acid. J Anal Appl 
Pyrolysis 49(1-2):307-317. https://doi.org/10.1016/ S0165-2370(98)00126-0.

Doroshenko A, Pylypenko I, Heaton K, Cowling S, Clark J, Budarin V (2019) Selective microwaveassisted pyrolysis of cellulose towards levoglucosenone with clay catalysts. ChemSusChem 12(24):5224-5227. https://doi.org/10.1002/cssc. 201903026.

Fukuhara K, Nakajima K, Kitano M, Kato H, Hayashi S, Hara M (2011) Structure and catalysis of cellulose-derived amorphous carbon bearing $\mathrm{SO}_{3} \mathrm{H}$ groups. ChemSusChem 4(6):778-784. https://doi.org/10.1002/cssc.201000431.

Guo HX, Lian YF, Yan LL, Qi XH, Smith RL (2013) Cellulose-derived superparamagnetic carbonaceous solid acid catalyst for cellulose hydrolysis in ionic liquid or aqueous reaction system. Green Chem 15(8):2167-2174. https://doi. org/10.1039/c3gc40433a.

Halpern Y, Riffer R, Broido A (1973) Levoglucosenone (1,6-anhydro-3,4-dideoxy-.DELTA.3-.beta.-Dpyranosen-2-one). Major product of the acid-catalyzed pyrolysis of cellulose and related carbohydrates. J Org Chem 38(2):204-209. https://doi.org/10.1021/jo00942a005.

Jiang LQ, Lin QL, Lin Y, Xu FX, Zhang X, Zhao ZL, Li HB (2020a) Impact of ball-milling and ionic liquid pretreatments on pyrolysis kinetics and behaviors of crystalline cellulose. Bioresour Technol 305:123044. https://doi.org/10.1016/j. biortech.2020.123044.

Jiang LQ, Wu YX, Zhao ZL, Li HB, Zhao K, Zhang F (2020b) Selectively biorefining levoglucosan from $\mathrm{NaOH}$ pretreated corncobs via fast pyrolysis. Cellulose 26:7877-7887. https://doi.org/10. 1007/s10570-019-02625-4.

Kudo S, Goto N, Sperry J, Narinaga K, Hayashi J (2017) Production of levoglucosenone and dihydrolevoglucosenone by catalytic reforming of volatiles from cellulose pyrolysis using supported ionic liquid phase. ACS Sustain Chem Eng 5(1):1132-1140. https://doi.org/10.1021/ acssuschemeng.6b02463.

Liu X, Carr P, Gardiner MG, Banwell MG, Elbanna AH, Zeinab G, Capon RJ (2020) Levoglucosenone and its pseudoenantiomer iso-levoglucosenone as scaffolds for drug discovery and development. ACS Omega 5(23):13926-13939. https://doi. org/10.1021/acsomega.0c01331.

Lu Q, Yang XC, Dong CQ, Zhang ZF, Zhang, XM, Zhu XF (2011) Influence of pyrolysis temperature and time on the cellulose fast pyrolysis products: Analytical Py-GC/MS study. J Anal Appl Pyrolysis 92(2):430-438. https://doi.org/10.1016/j. jaap.2011.08.006.

Lu Q, Ye XN, Zhang ZB, Dong CQ, Zhang Y (2014a) Catalytic fast pyrolysis of cellulose and biomass to produce levoglucosenone using magnetic $\mathrm{SO}_{4}{ }^{2-} / \mathrm{TiO}_{2}-\mathrm{Fe}_{3} \mathrm{O}_{4}$. Bioresour Technol 171:10-15. https://doi.org/10.1016/j.biortech.2014.08. 075.

Lu Q, Zhang Y, Dong CQ, Yang YP, Yu HZ (2014b) The mechanism for the formation of levoglucosenone during pyrolysis of beta-D-glucopyranose and cellobiose: A density functional theory study. J Anal Appl Pyrolysis 110:34-43. https://doi.org/10.1016/j.jaap.2014.08.002.

Maduskar S, Maliekkal V, Neurock M, Dauenhauer PJ (2018) On the yield of levoglucosan from cellulose pyrolysis. ACS Sustain Chem Eng 6(5):7017-7025. https://doi.org/10.1021/acssus chemeng.8b00853.

Meng X, Zhang HY, Liu C, Xiao R (2016) Comparison of acids and sulfates for producing levoglucosan and levoglucosenone by selective catalytic fast pyrolysis of cellulose using PyGC/MS. Energy Fuels 30(10):8369-8376. https://doi.org/10. 1021/acs.energyfuels.6b01436.

Mullen CA, Boateng AA (2010) Catalytic pyrolysis-GC/MS of lignin from several sources. Fuel Process Technol 91(11):1446-1458. https://doi.org/10.1016/j.fuproc. 2010.05.022.

Shafizadeh F, Furneaux RH, Stevenson TT, Cochran TG (1978) Acid-catalyzed pyrolytic synthesis and decomposition of 1,4-3,6-dianhydro-alpha-d-glucopyranose. Carbohydr Res 61(1):519-528. https://doi.org/10.1016/S0008-6215(00)84510-3.

Sharifzadeh M, Sadeqzadeh M, Guo M, Borhani TN, Konda NVSNM, Garcia MC, Wang L, Hallett J, Shah N (2019) The multi-scale challenges of biomass fast pyrolysis and bio-oil upgrading: Review of the state of art and future research directions. Prog Energy Combust Sci 71:1-80. https://doi.org/10.1016/j.pecs.2018. 10.006.

Tshikesho RS, Kumar A, Huhnke RL, Apblett A (2019) Catalytic co-pyrolysis of red cedar with methane to produce upgraded bio-oil. Bioresour Technol 285:121299. https://doi.org/10.1016/j. biortech.2019.03.138.

Usino DO, Supriyanto, Ylitervo P, Pettersson A, Richards T (2020) Influence of temperature and time on initial pyrolysis of cellulose and xylan. J Anal Appl Pyrolysis 147:104782. https://doi.org/10. 1016/j.jaap.2020.104782.

Wang Z, Lu Q, Zhu XF, Zhang Y (2011) Catalytic fast pyrolysis of cellulose to prepare levoglucosenone using sulfated zirconia. ChemSusChem 4(1):79-84. https://doi.org/10.1002/cssc. 201000210.

Ye XN, Lu Q, Wang X, Guo HQ, Cui MS, Dong CQ, Yang YP (2017) Catalytic fast pyrolysis of 
cellulose and biomass to selectively produce levoglucosenone using activated carbon catalyst. ACS Sustain Chem Eng 5(11):10815-10825. https://doi. org/10.1021/acssuschemeng.7b02762.

Zhang F, Xu LJ, Xu FX, Jiang LQ (2021) Different acids pretreatments at room temperature boost selective saccharification of lignocellulose via fast pyrolysis. Cellulose 28:81-90. https://doi.org/ 10.1007/s10570-020-03544-5.

Zhang HY, Meng X, Liu C, Wang Y, Xiao R (2017) Selective low-temperature pyrolysis of microcrystalline cellulose to produce levoglucosan and levoglucosenone in a fixed bed reactor. Fuel Process. Technol 167:484-490. https://doi.org/10.1016/j.fuproc.2017.08.007.

Zhang JK, Xu YJ, Wang WQ, Griffin J, Roozeboom K, Wang DH (2020) Bioconversion of industrial hemp biomass for bioethanol production: A review. Fuel 281:118725. https://doi.org/10.1016/j. fuel.2020.118725.

Zhang Y, Lei H, Yang Z, Qian K, Villota E (2018) Renewable high-purity mono-phenol production from catalytic microwave-induced pyrolysis of cellulose over biomass-derived activated carbon catalyst. ACS Sustain Chem Eng 6(4):5349-5357. https://doi.org/10.1021/acssuschemeng.8b001 29. 
Figures
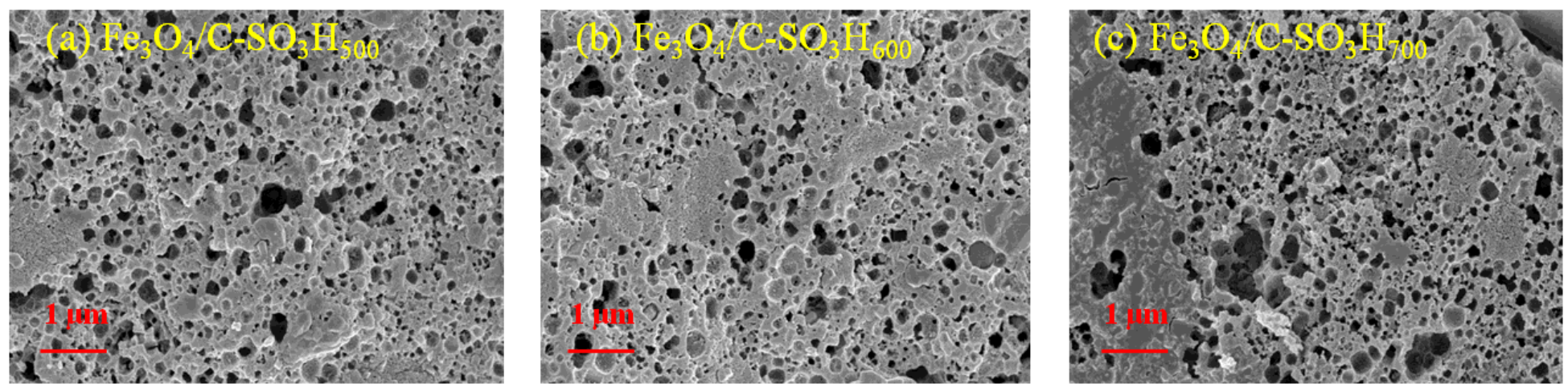

Figure 1

SEM images of catalysts.

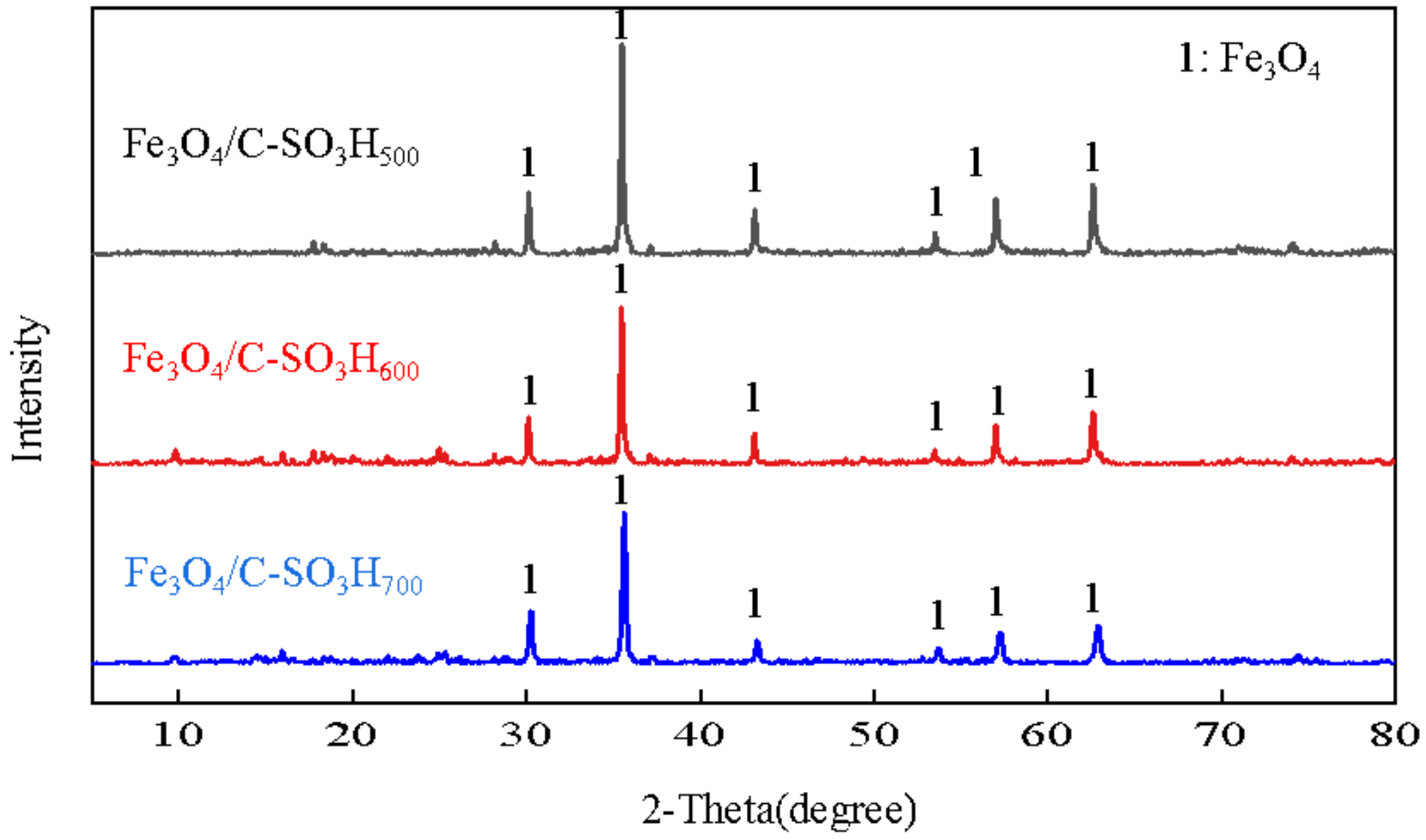

Figure 2

XRD patterns of catalysts. 


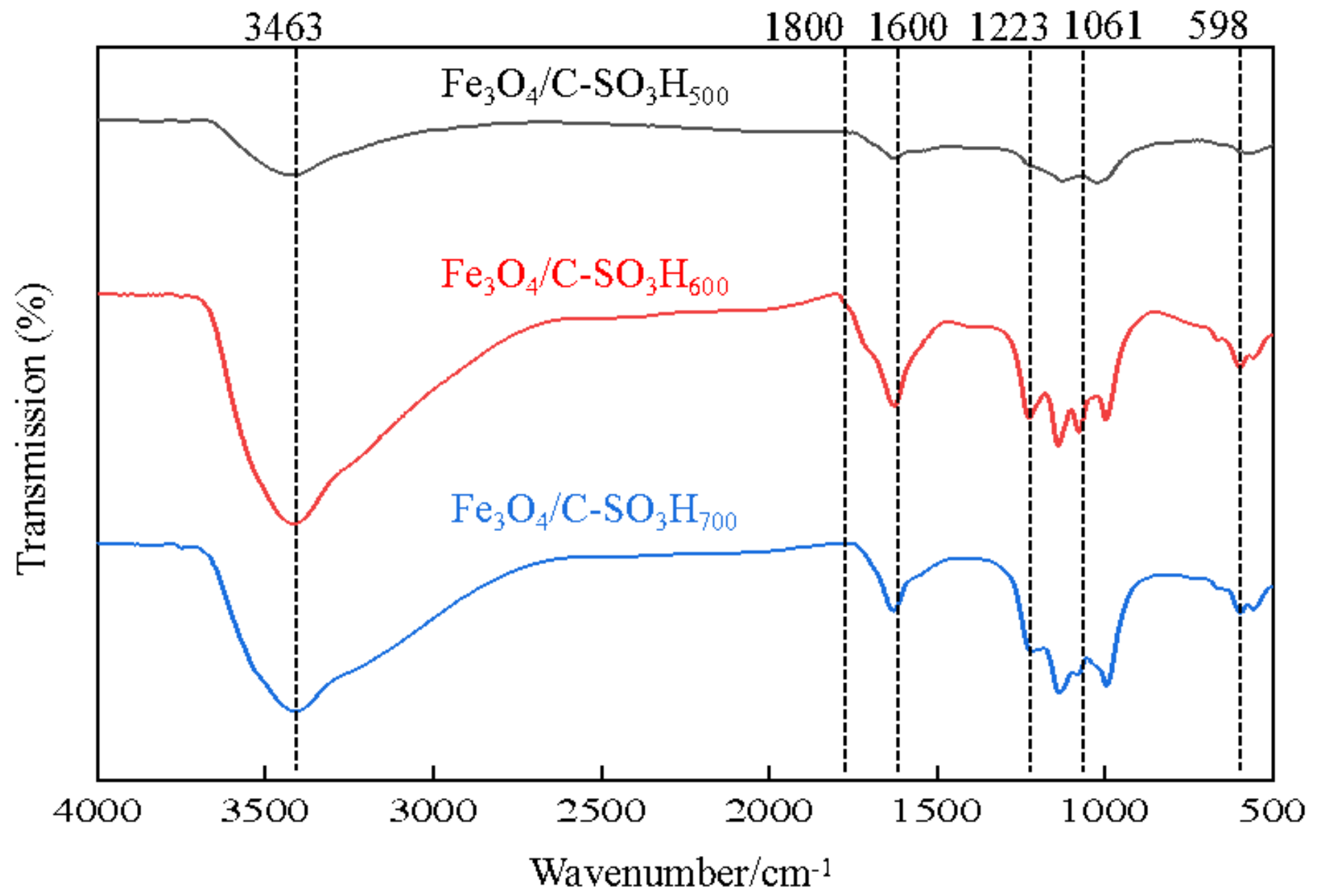

Figure 3

FTIR analysis of catalysts.
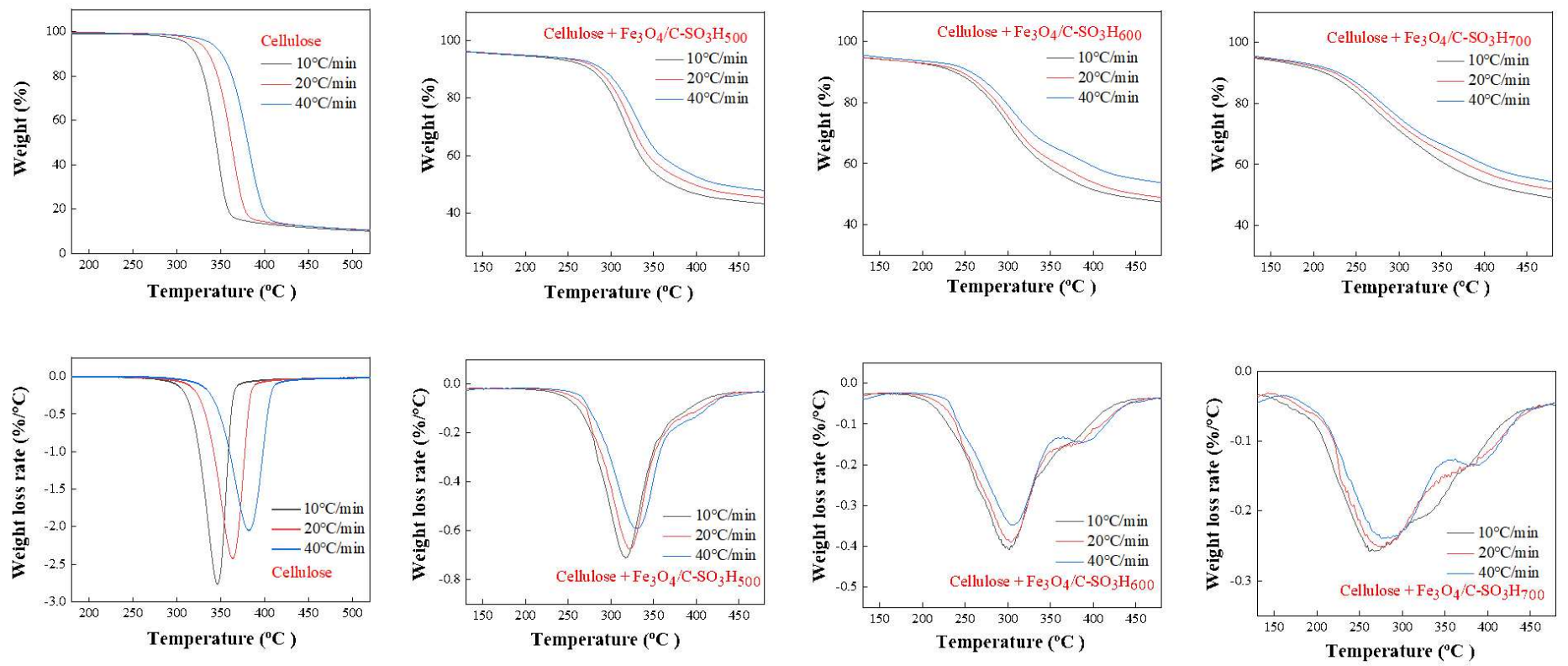
Figure 4

TG and DTG curves of cellulose and cellulose mixed with catalyst.
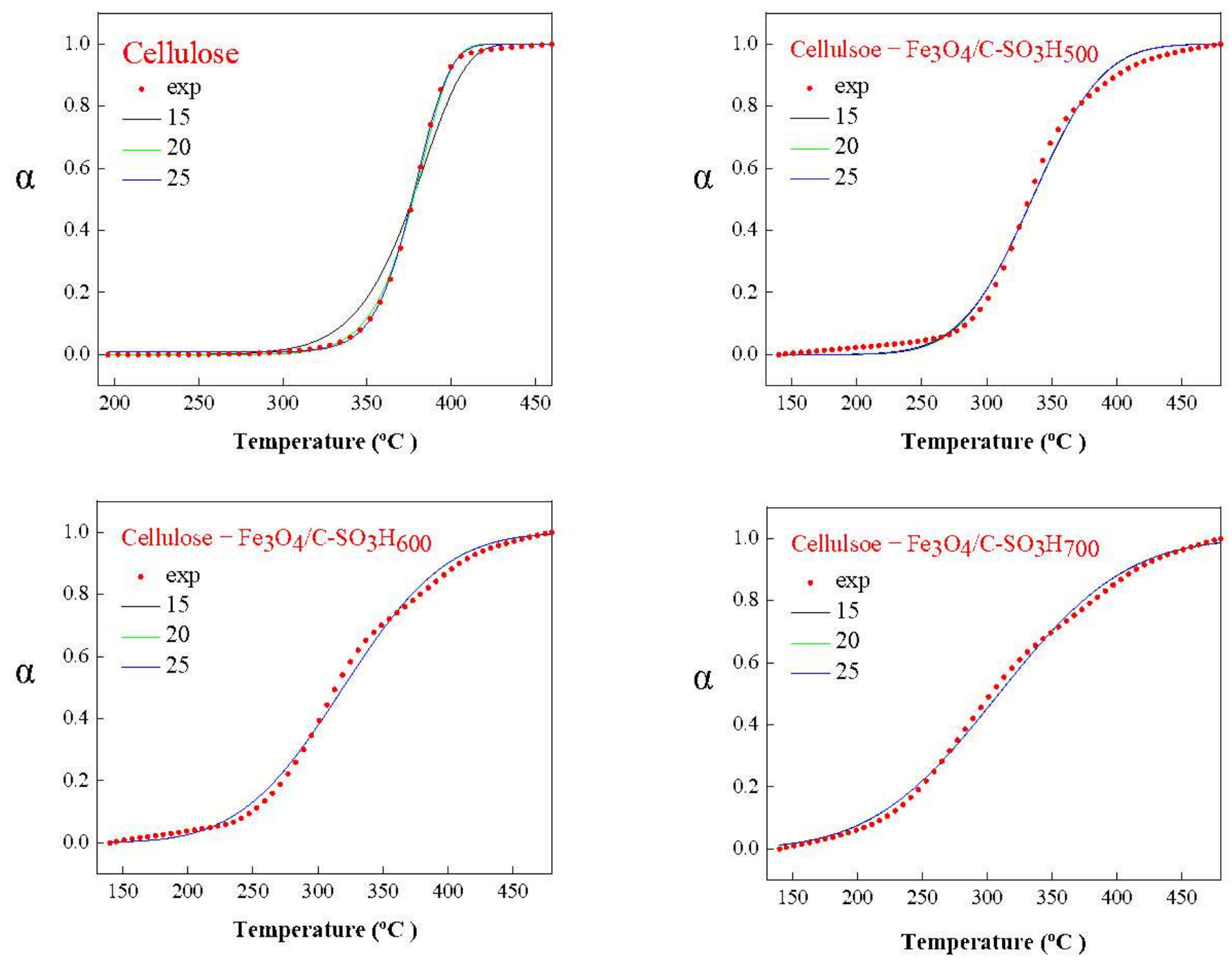

Figure 5

The experimental curve and curve fitted by DAEM model. 


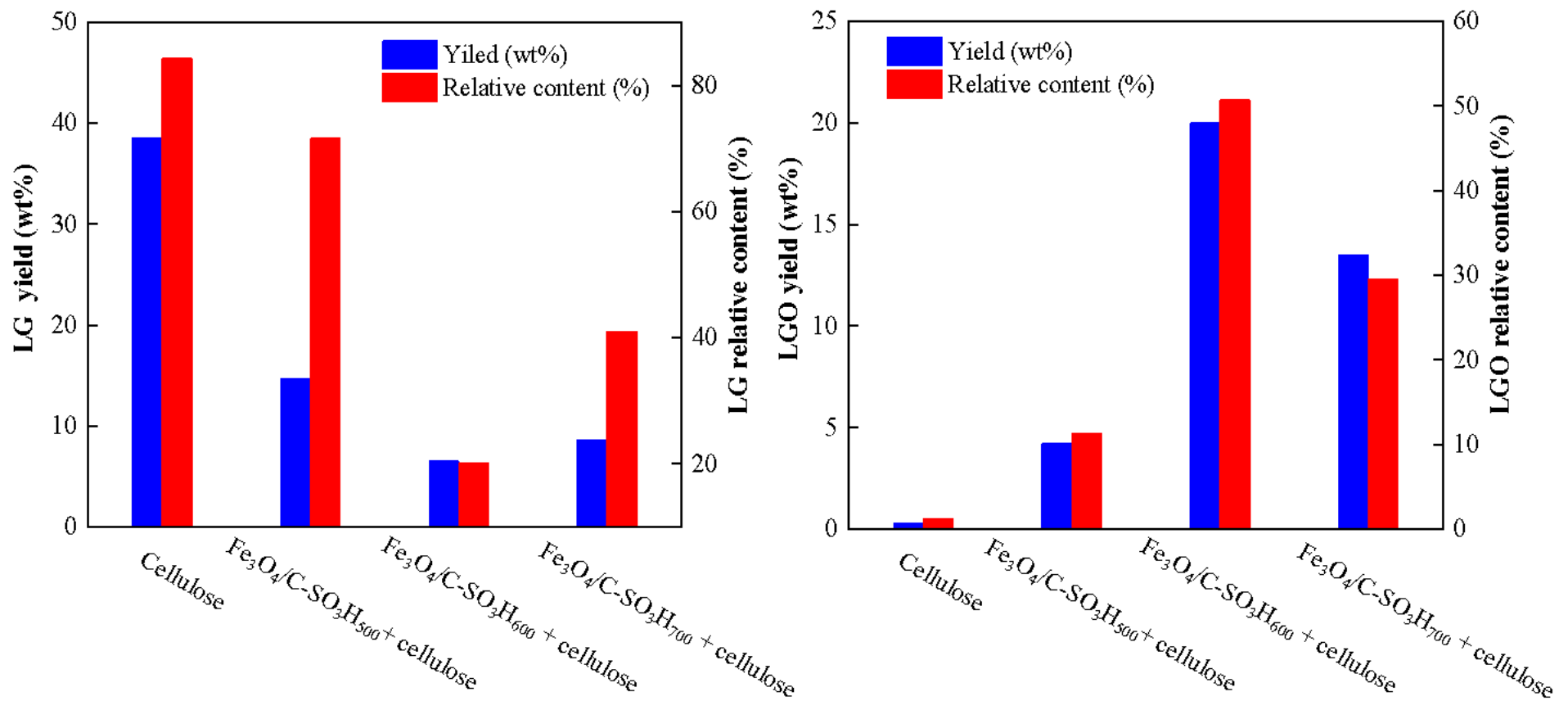

Figure 6

The effect of three catalysts to pyrolyze cellulose on the yield and relative content of LG and LGO.
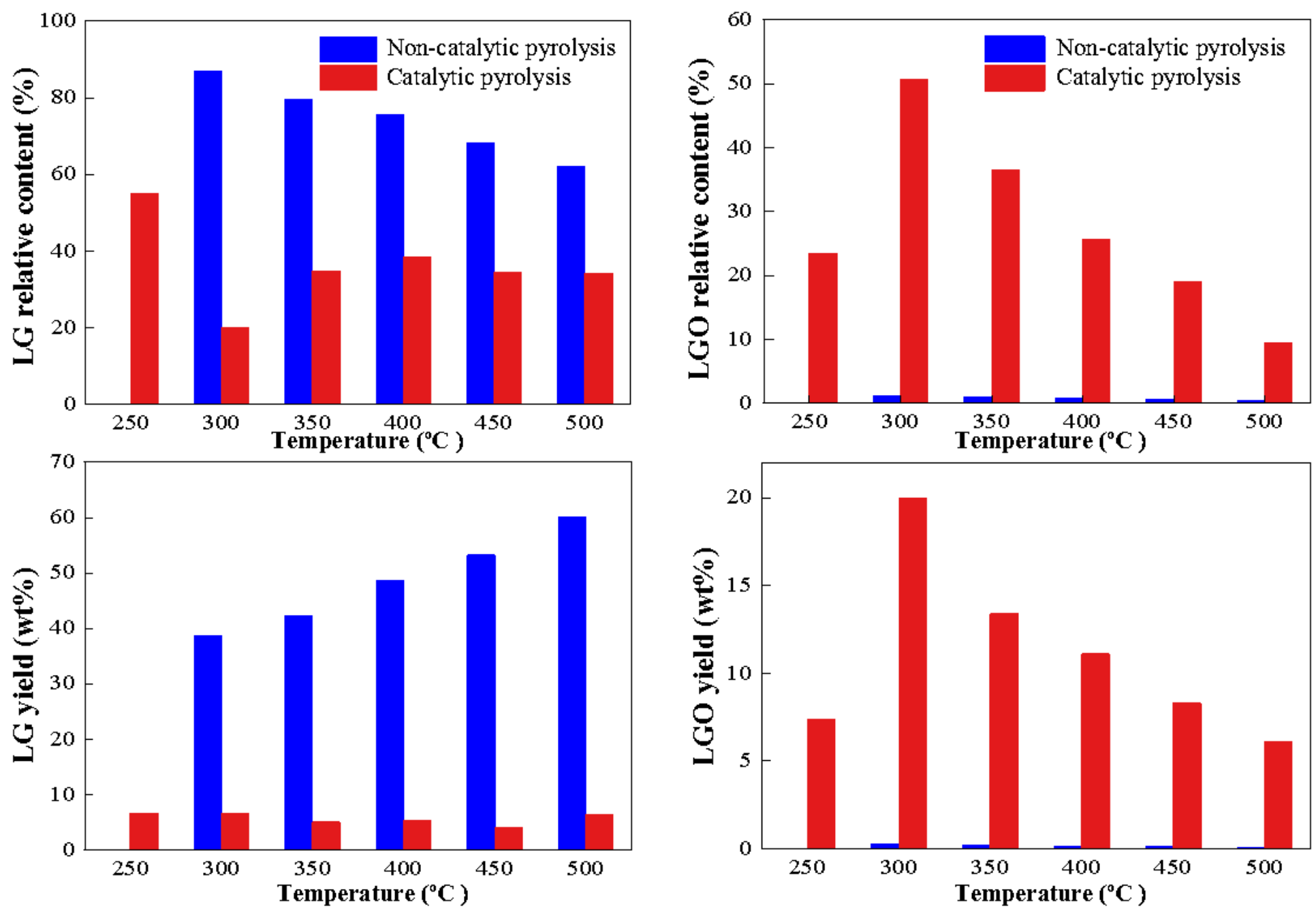
Figure 7

Effect of the temperature on the relative content and yield of LG and LGO.
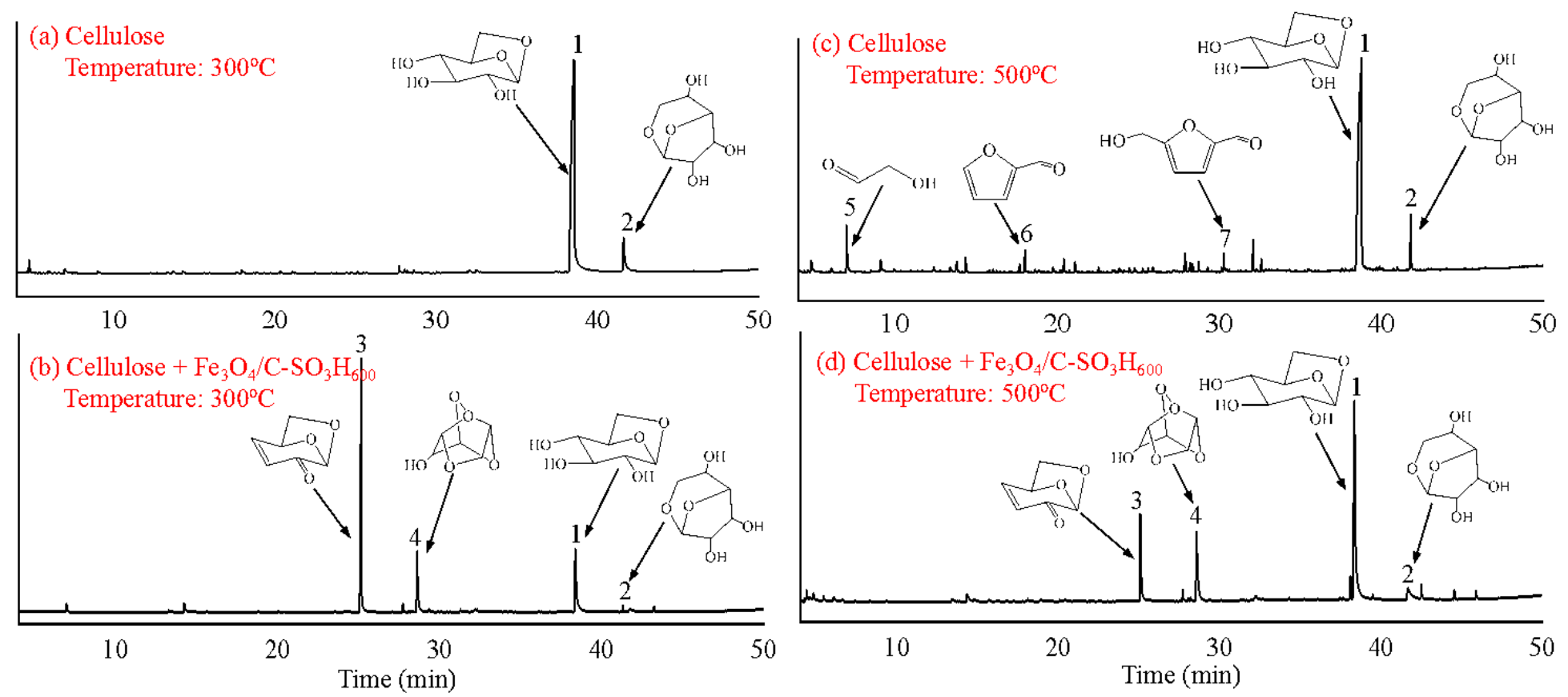

Figure 8

Typical ion chromatograms of cellulose pyrolysis: (a) cellulose in noncatalytic pyrolysis at $300^{\circ} \mathrm{C},(\mathrm{b})$ cellulose in catalytic pyrolysis at $300^{\circ} \mathrm{C}$, (c) cellulose in noncatalytic pyrolysis at $500^{\circ} \mathrm{C}$, (d) cellulose in catalytic pyrolysis at $500^{\circ} \mathrm{C}$, (1) LG, (2) AGF, (3) LGO, (4) DGP, (5) HAA, (6) FF, (7) 5-HMF.

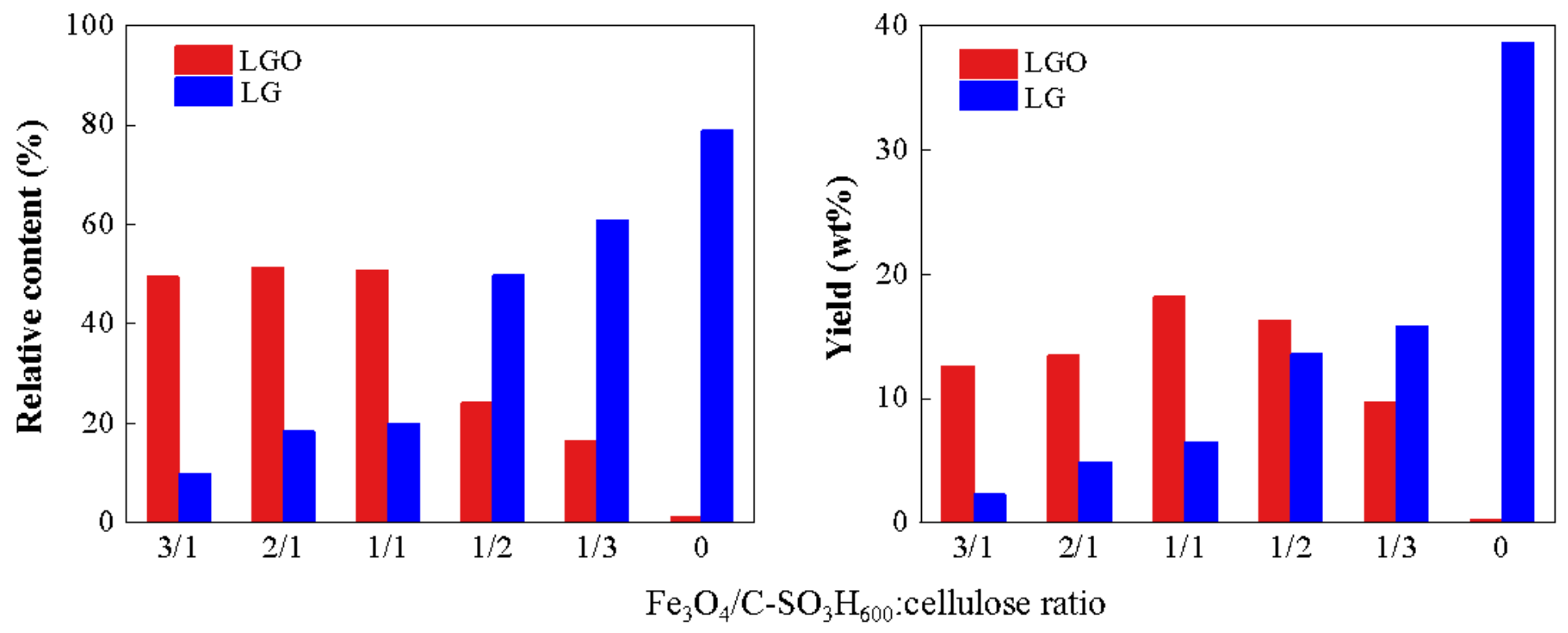

Figure 9

Effect of Fe304/C-SO3H600-to-cellulose ratio on the relative content and yield of LG and LGO at $300{ }^{\circ} \mathrm{C}$. 


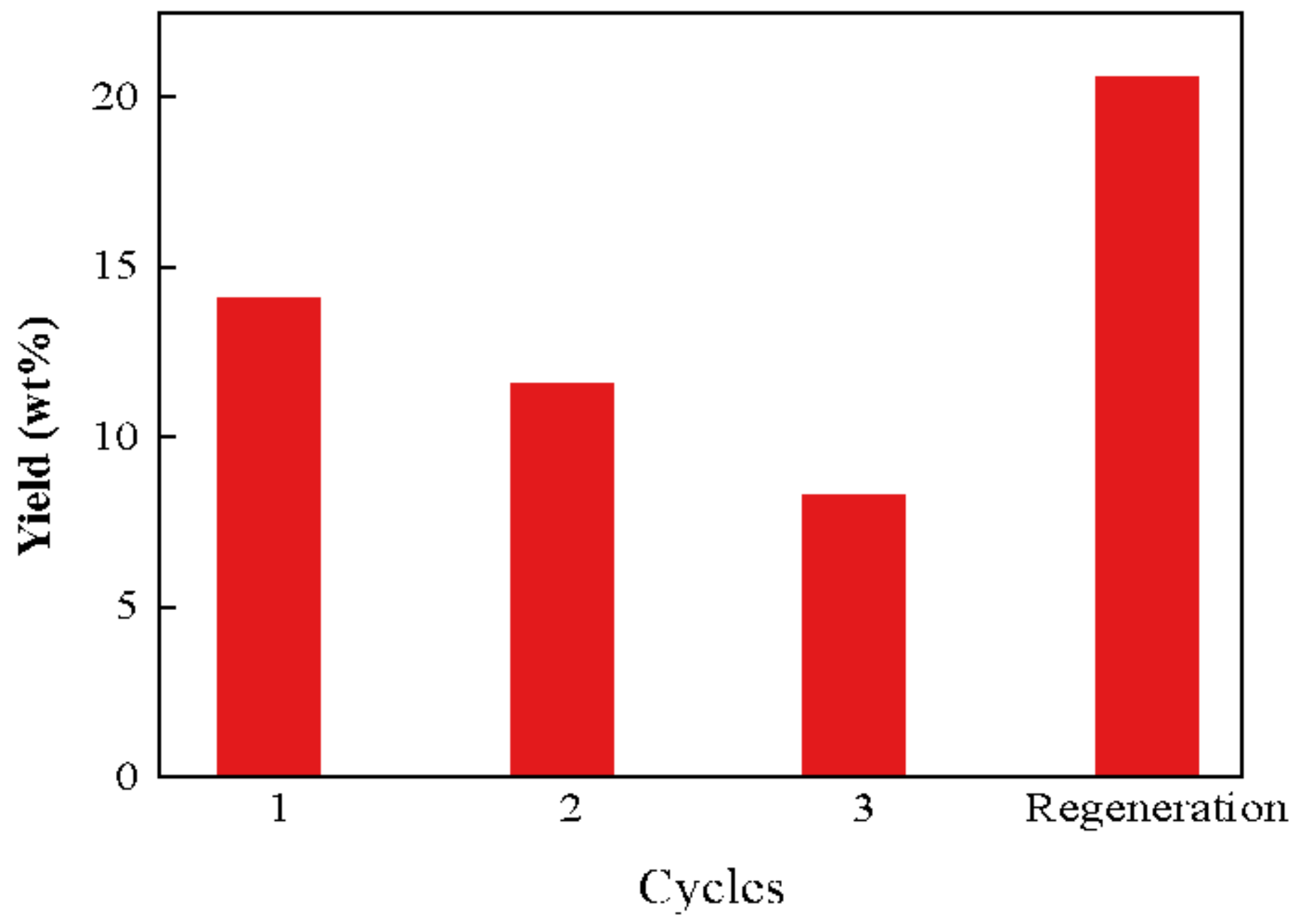

Figure 10

Effect of catalyst cycle on LGO yield at $300{ }^{\circ} \mathrm{C}$. 


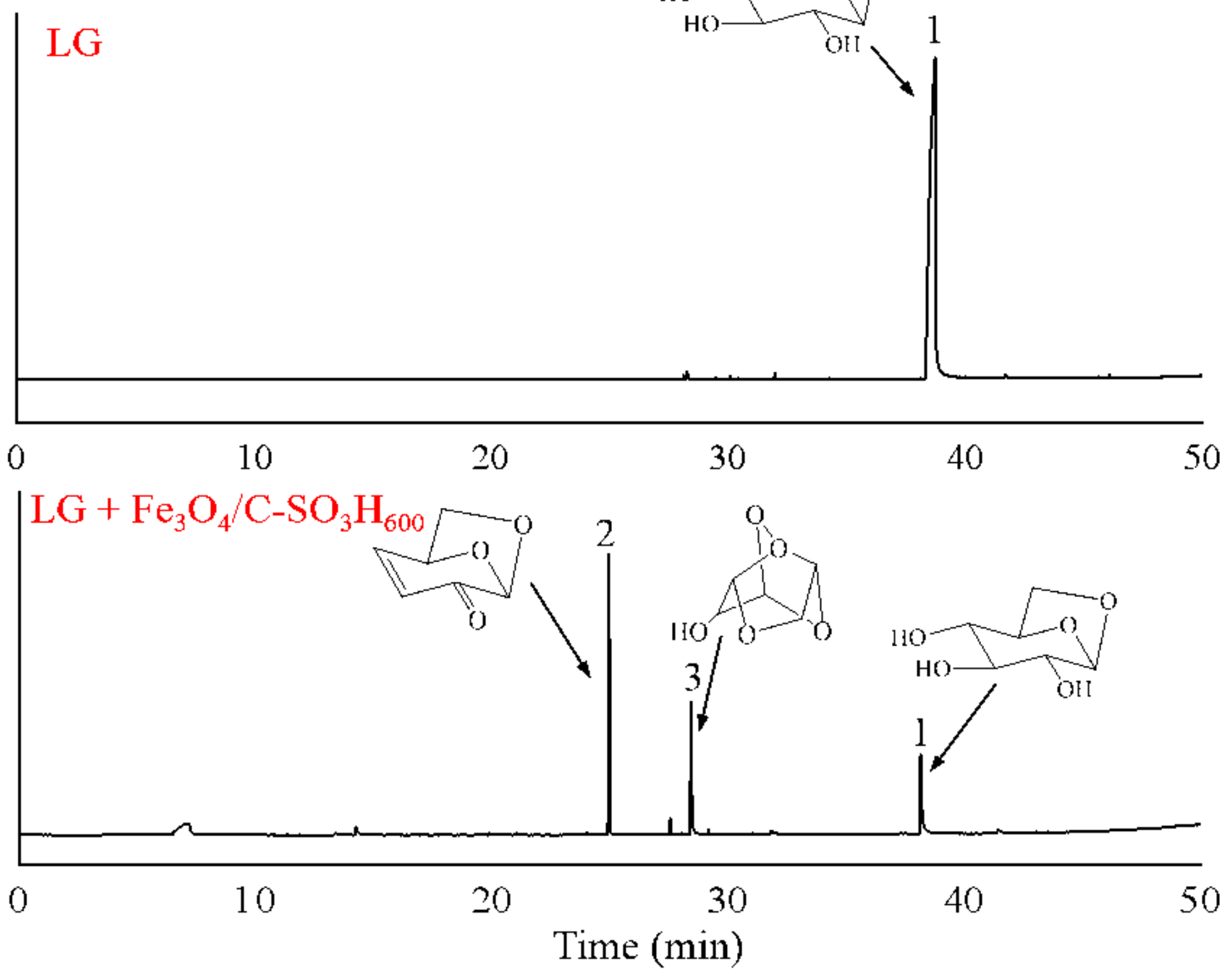

Figure 11

Typical ion chromatograms of LG in noncatalytic and catalytic pyrolysis: (1) LG, (2) LGO, (3) DGP. 


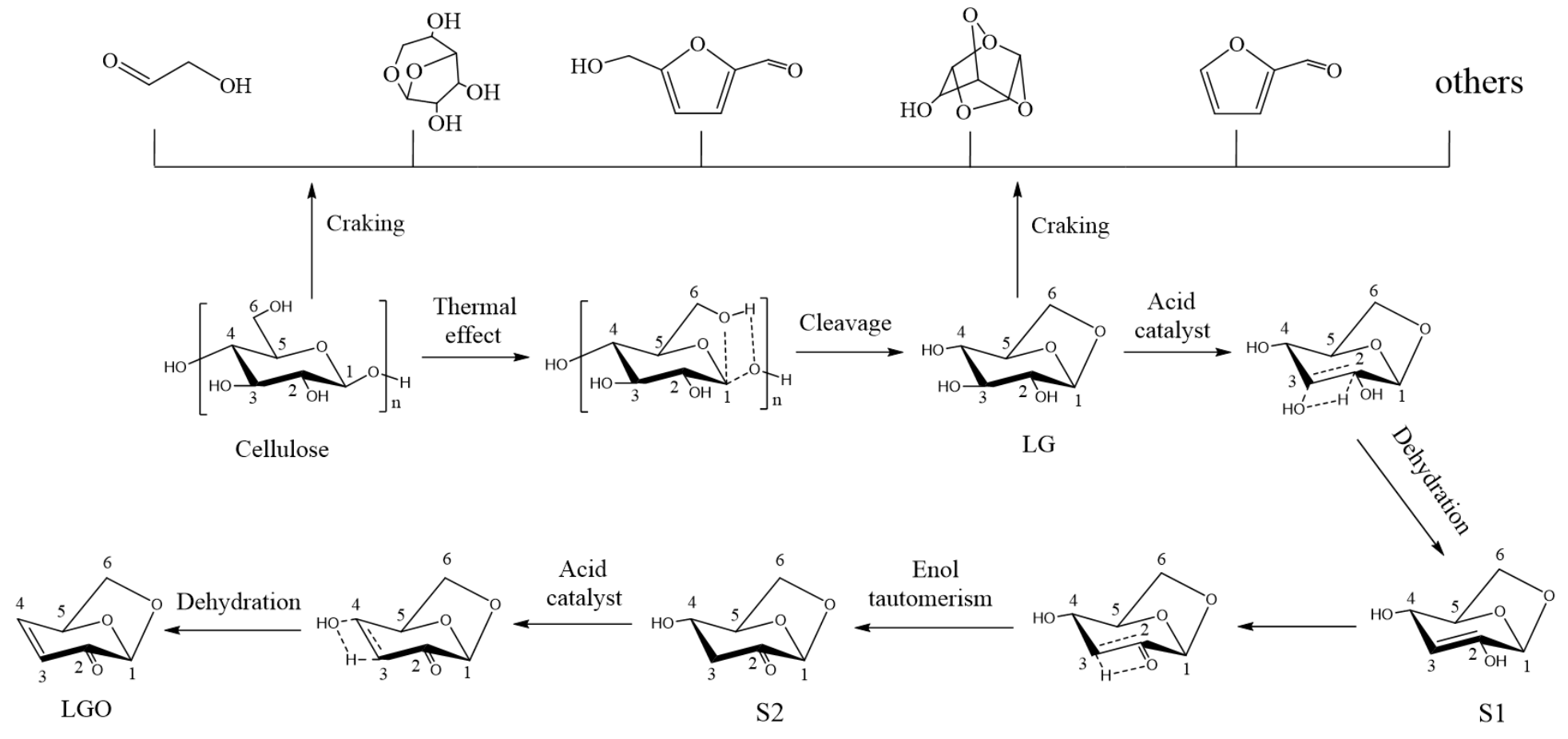

Figure 12

Possible reaction mechanism of catalytic fast pyrolysis of cellulose for LG and LGO production. 